\title{
Middle East Respiratory Syndrome Coronavirus (MERS-CoV): State of the Science
}

\author{
Ahmed Mostafa ${ }^{1}\left(\mathbb{D}\right.$, Ahmed Kandeil ${ }^{1}\left(\mathbb{D}\right.$, Mahmoud Shehata ${ }^{1}(\mathbb{D})$ Rabeh El Shesheny ${ }^{1,2} \mathbb{D}$, \\ Abdallah M. Samy ${ }^{3}\left(\mathbb{D}\right.$, Ghazi Kayali ${ }^{4,5, *}$ and Mohamed A. Ali ${ }^{1, * \mathbb{D}}$ \\ 1 Center of Scientific Excellence for Influenza Viruses, Environmental Research Division, National Research \\ Centre (NRC), Cairo 12622, Egypt; ahmed_nrc2000@hotmail.com (A.M.); \\ Ahmed.Kandeil@human-link.org (A.K.); Mahmoud.Shehata@human-link.org (M.S.); \\ ra_eny@yahoo.com (R.E.S.) \\ 2 Department of Infectious Diseases, St. Jude Children's Research Hospital, Memphis, TN 38105, USA \\ 3 Entomology Department, Faculty of Science, Ain Shams University, Abbassia, Cairo 11566, Egypt; \\ samy@sci.asu.edu.eg \\ 4 Department of Epidemiology, Human Genetics, and Environmental Sciences, University of Texas, \\ Houston, TX 77030, USA \\ 5 Human Link, Baabda 1109, Lebanon \\ * Correspondence: ghazi@human-link.org (G.K.); mohamedahmedali2004@yahoo.com (M.A.A.); \\ Tel.: +20-237481483 (M.A.A.)
}

Received: 17 June 2020; Accepted: 30 June 2020; Published: 2 July 2020

\begin{abstract}
Coronaviruses belong to a large family of viruses that can cause disease outbreaks ranging from the common cold to acute respiratory syndrome. Since 2003, three zoonotic members of this family evolved to cross species barriers infecting humans and resulting in relatively high case fatality rates (CFR). Compared to Severe Acute Respiratory Syndrome Coronavirus (SARS-CoV, CFR = 10\%) and pandemic Severe Acute Respiratory Syndrome Coronavirus 2 (SARS-CoV-2, CFR =6\%), the Middle East Respiratory Syndrome Coronavirus (MERS-CoV) has scored the highest CFR (approximately $35 \%$ ). In this review, we systematically summarize the current state of scientific knowledge about MERS-CoV, including virology and origin, epidemiology, zoonotic mode of transmission, and potential therapeutic or prophylactic intervention modalities.
\end{abstract}

Keywords: MERS-CoV; epidemiology; coronavirus; zoonotic disease

\section{Introduction}

Coronaviruses (CoVs) belong to the Coronaviridae family and Nidovirales order. They are enveloped, positive-sense, single-stranded RNA viruses, with the largest genome of all RNA viruses (26-32 kb) [1]. Based on their genetic and antigenic relationships, the International Committee for Taxonomy of Viruses (ICTV) classified CoVs into four genera: Alpha-, Beta-, Gamma-, and Delta-CoVs [2]. CoVs have the capability of interspecies transmission to induce asymptomatic to serious infections in humans, bats, mice, poultry, pets, pigs, and cattle, causing mainly respiratory and enteric diseases [3].

A novel human coronavirus, the Middle East Respiratory Syndrome Coronavirus (MERS-CoV), was first identified in September 2012 in the Kingdom of Saudi Arabia (KSA) in a patient with fever, cough, expectoration, and dyspnea [4]. Since the first case, MERS-CoV has spread globally, causing 2499 human infections including 861 deaths in 27 countries (Asia, Europe, Africa, and North America) as of December 2019 [5,6]. Most cases were reported in countries of the Arabian Peninsula, especially KSA [7,8]. This MERS-CoV outbreak reminded the international public health authorities of the Severe Acute Respiratory Syndrome outbreak of the early 2000s that was caused by another CoV, the Severe 
Acute Respiratory Syndrome Coronavirus (SARS-CoV) [9]. Even though both SARS- and MERS-CoV belong to the same family, the SARS-CoV outbreak in 2003 was associated with a high incidence rate due to its efficient human-to-human transmission, but low case fatality rate (10\%). In contrast, MERS-CoV was relatively inefficiently transmitted between humans but had a high case fatality rate of $35 \%[10,11]$.

Two clades of MERS-CoV (i.e., Clade A and B) were recognized based on phylogenetic analysis of viral genomes [12]. The viral genomes detected in the earliest cases in humans (clade A cluster; EMC/2012 and Jordan-N3/2012) were genetically distinct from viruses in clade B circulating in most cases identified later [13]. Recently, an additional clade was identified from the African MERS-CoV strains collected from camels in Africa [14].

Bats have been recognized as a reservoir of most zoonotic coronaviruses $[15,16]$. MERS-CoV was closely related to bat coronaviruses, supporting the hypothesis that the MERS-CoV infection is zoonotic, where the virus is maintained in an animal reservoir [17-19]. Dromedary camels (Camelus dromedarius) were also identified as intermediate hosts allowing the MERS-CoV to spread to humans via airborne transmission [20]. High seroprevalence of MERS-CoV was identified in domestic camels [13,14,21-32]. The latter evidence was confirmed in camel samples collected from KSA, Qatar, United Arab Emirates (UAE), Oman, Jordan, Egypt, Nigeria, Kenya, Tunisia, Morocco, Burkina Faso, Ethiopia, Israel, and Spain [13,14,21-32]. Circulation of MERS-CoV in dromedary camels may drive the transmission in human populations.

Numerous MERS-CoV cases have developed severe symptoms approaching respiratory and kidney failure; however, some MERS-CoV infections appeared asymptomatic [33]. The elevated virulence of MERS-CoV is associated with high case fatality rate (approximately $35 \%$ ) according to the WHO and FAO official reports [5,6]. Nevertheless, the MERS-CoV mortality rate is overestimated owing to lack of data on asymptomatic and mild cases.

\section{MERS-CoV Origin of Transmission}

The origin and transmission scheme of MERS-CoV remain unknown. The bat origin of MERS-CoV was a strong hypothesis considering the high genome relatedness between sequences of bat coronaviruses and MERS-CoV [34]. Both bat-CoVs (HKU4) and MERS-CoV have the same receptor DPP4 in cell tropism features [35-37] Interestingly, MERS-CoV full genome isolation from bats has not been recorded until now, so bat to human transmission of the virus is uncertain.

The epidemiological studies in KSA showed that human antibodies against MERS-CoV were still at low prevalence [38,39]. Out of 10,009 individuals of the general population of KSA, only 15 were seropositive $(0.15 \%)$ [40]. In another report, seven subjects $(3.1 \%)$ of 87 camel workers and 140 slaughterhouse workers were confirmed positive for MERS-CoV antibodies [41]. Surprisingly, 5000 pilgrims from 22 different nations, who travelled to KSA for Hajj in 2013, were diagnosed negative by PCR for MERS-CoV infection [42]. In the light of current knowledge, the MERS-CoV transmission scheme and origin are illustrated in Figure 1. 


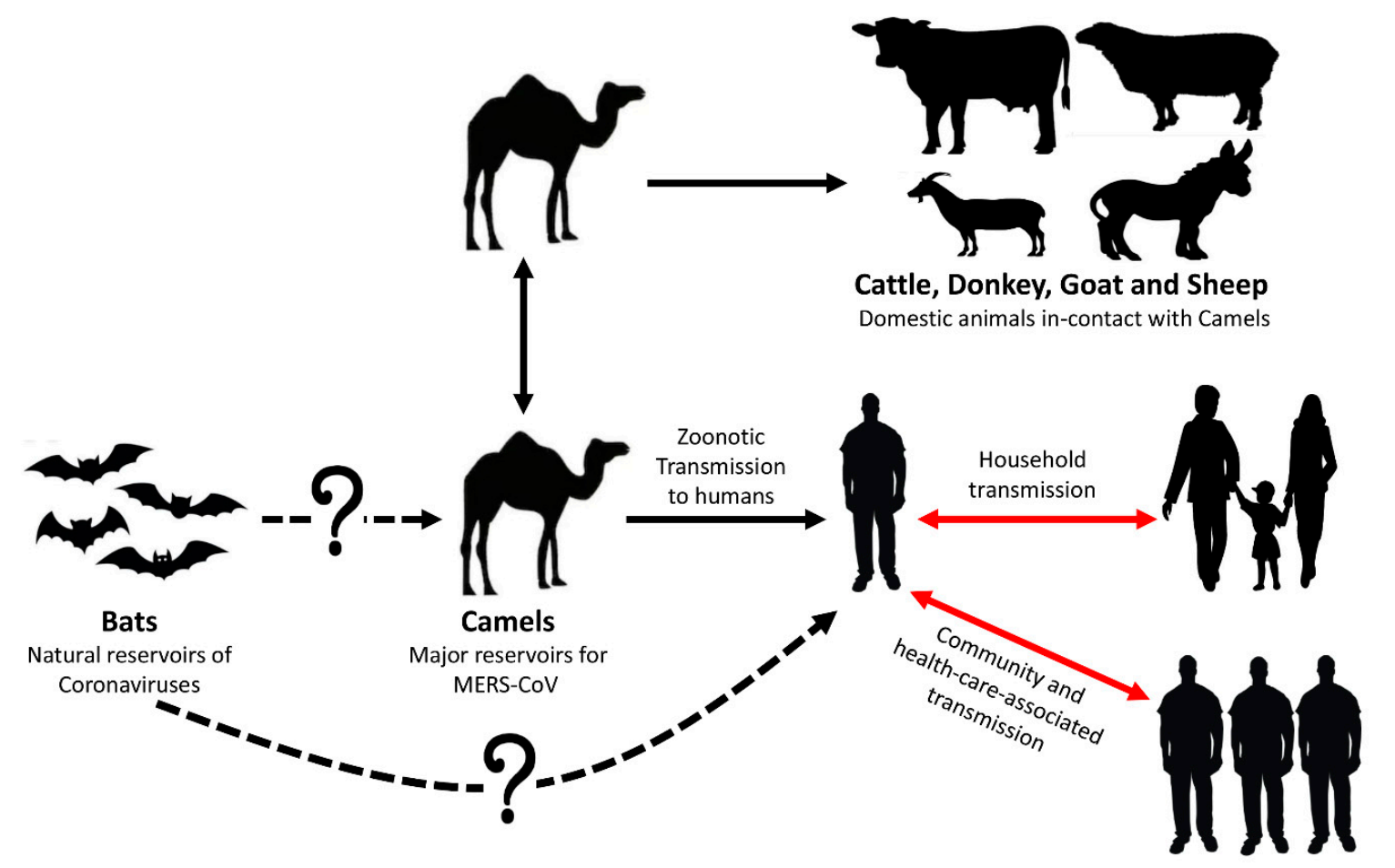

Figure 1. Zoonotic mode of transmission of MERS-CoV. The three routes of transmission (camel-to-camel, camel-to-human, and human-to-human) were confirmed. The prevalence of MERS-CoV in domestic animals in-contact with camels was recently identified [43]. As depicted by the dotted line, bat-to-camel and bat-to-human direct transmission of MERS-CoV have not been confirmed. Human-to-human transmission of the virus occurs after close contact with an infected case in households and healthcare settings (red arrows).

Until now, dromedary camels have likely been the main zoonotic source for human infections. MERS-CoV antibodies have already been detected in nearly all dromedary camels examined in the Arabian Peninsula and several African countries [22-24,31,44-47]. Camels in other parts like Europe, Australia, and Americas do not have MERS-CoV antibodies and have no evidence of infection $[26,48]$.

Some human infections with MERS-CoV were linked to exposure to camels; the first evidence was a study in KSA in which the full genome sequences of MERS-CoV were identical in isolates from both a human case with a fatal infection and his camels [49]. These results suggest that MERS-CoV can infect dromedary camels and can be transmitted from infected camels to humans by direct close contact [49]. Furthermore, phylogenetic analyses of the MERS-CoV genome from camel and human isolates demonstrated that the viruses were highly identical or in some cases were similar to each other $[13,50,51]$.

\section{Epidemiology of MERS-CoV in Animals}

\subsection{MERS-CoV Infection in Dromedary Camels}

Mild disease of the upper respiratory tract (URT) or no apparent disease has been observed in young and adult camels naturally infected with MERS-CoV [13,52]. However, experimental infections indicated that MERS-CoV in adult dromedaries results in a mild respiratory disease with purulent nasal discharge [53]. Although clinical signs of the MERS-CoV infection in camels are benign, camels shed large quantities of virus from their URT [52,53]. Experimentally, Adney and his colleagues detected infectious MERS-CoV particles and viral RNA in nasal secretions between 7 days and 35 days post-infection [53]. MERS-CoV genome was detected in nasal swabs of dromedaries in the Arabian Peninsula, Egypt, Iran, Israel, Pakistan, Senegal, and Tunisia [24,54], and the virus was isolated from 
dromedaries in Egypt, KSA, and Qatar [27,55]. For instance, MERS-CoV RNA has been detected in camel nasal swabs $(n=96$, positivity $=29.2 \%)$ and lung tissue samples $(n=91$, positivity $=61.5 \%)$ during April 2013-May 2014 in Al-Ahsa Province, KSA [56]. This high prevalence of MERS-CoV in camels is attributed to the abundance of the cellular dipeptidyl peptidase 4 (DPP4), which is responsible for binding with MERS-CoV spike protein to initiate the infection, in the URT epithelium of camels $[53,55]$.

\subsection{Sero-Prevalence of MERS-CoV in Domestic Animals}

Serological studies on various animal species in the Middle East were carried out to assess zoonotic potential of MERS-CoV infections [26]. Dromedary camels (Camelus dromedarius) appeared to be the source of MERS-CoV. Camel sera from Oman, Canary Islands, and Egypt were positive for MERS-CoV antibodies in about $100 \%, 14 \%$, and 90\%, respectively [29,30,46]. Retrospective studies on archived human sera showed no evidence for infection with MERS-CoV before 2012 [39], but MERS-CoV antibodies were detected in archived camel sera in KSA from 1993 [26], and UAE from 2003 [25], indicating that MERS-CoV viruses were silently circulating in camels long before they were discovered in 2012. Bactrian camels in Mongolia tested negative for MERS-CoV antibodies [57]. The serological studies in domestic animals in contact with camels in the same housing area showed antibodies against MERS-CoV in Egypt, Tunisia, and Senegal [43,58]. The serological evidence of MERS-CoV prevalence in dromedary and domestic animals are listed in Table 1.

Table 1. Serological evidence of MERS-CoV prevalence in dromedary and domestic animals in the field.

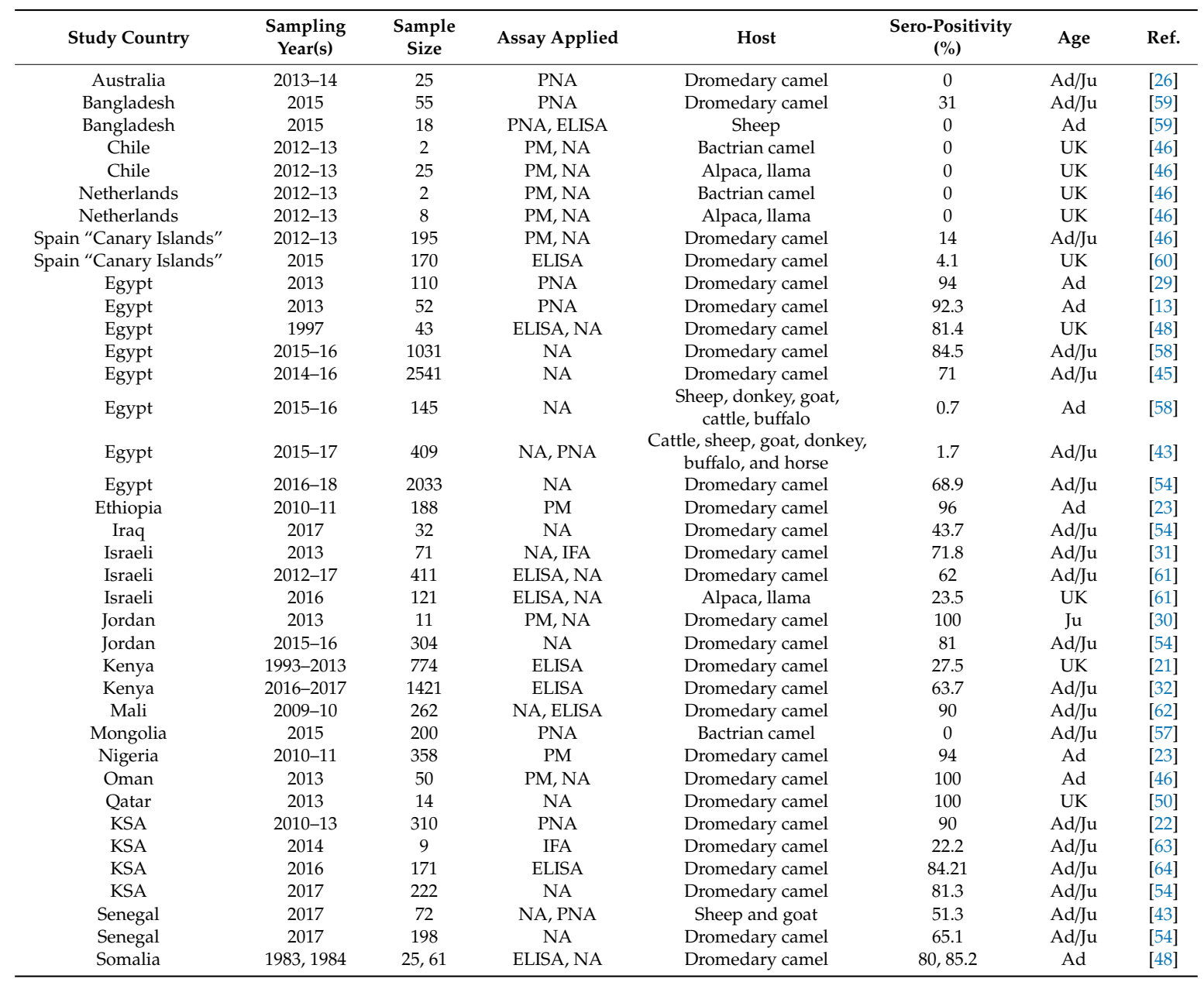


Table 1. Cont.

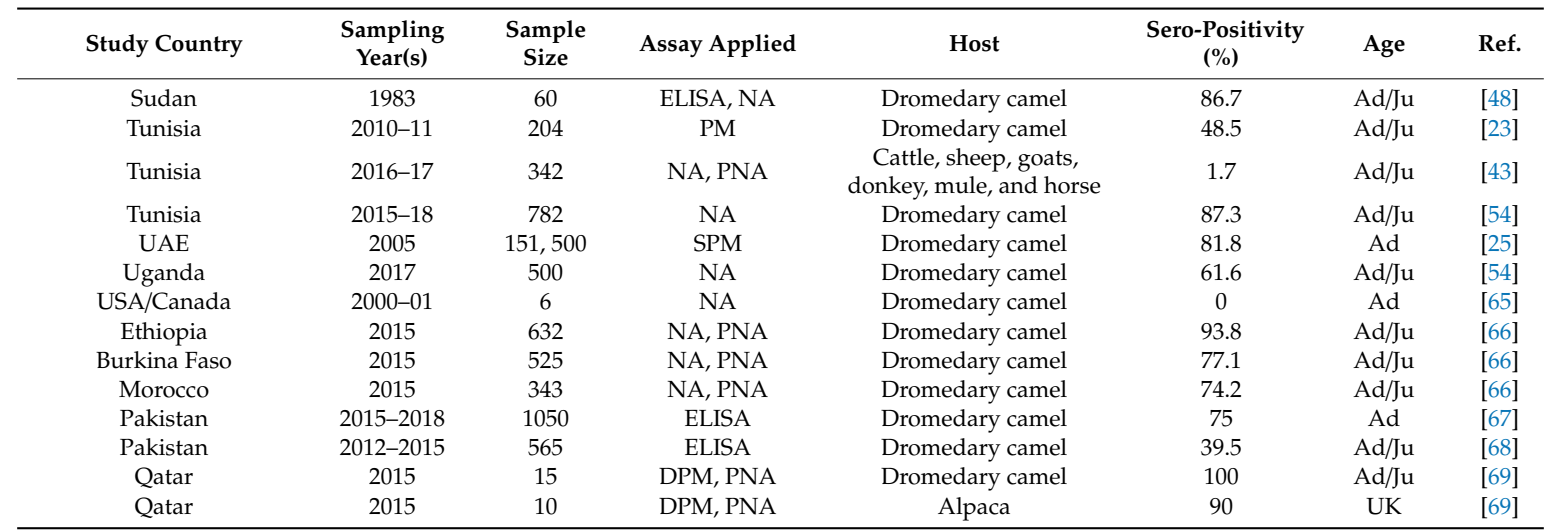

Abbreviations: PNA (Pseudoparticle Neutralization Assay); NA (Neutralization Assay); IFA (Immunofluorescence Assay); PM (Protein Microarray); SPM (Spike Protein Microarray); ELISA (Enzyme-Linked Immunosorbent Assay); Ad (Adult); Ju (Juvenile); Ad/Ju (Adult and Juvenile); UK (Unknown).

\section{Epidemiology of MERS-CoV in Humans}

Unlike camels, the human URT lacks DPP4 expression, and this may be the primary cause of limited MERS-CoV replication and hence restricted human-to-human transmission [53]. Most human infections have been reported in KSA (2073 cases; case fatality rate $=37 \%)$ and UAE (87 cases) with an evidence of case clusters in these countries [6,70-72]. Cases outside the Arabian Peninsula have been documented in Europe, Asia, North Africa, and North America, and were reported in travelers returning to their countries from the Arabian Peninsula region [73-75].

\subsection{Distribution Pattern and Human Infections in Middle East}

In September 2012, the MERS-CoV was first isolated from a Saudi citizen (60 years old), who manifested kidney failure and acute pneumonia. Afterwards, a case from Qatar was reported with the same symptoms and who had a travel history to KSA [4,76,77]. Many cases have been subsequently reported from Middle East countries [78].

MERS-CoV has been largely detected in the Middle East region, especially in the Arabian Peninsula, where large numbers of dromedary camels are reared. The serological and virological inspections of camels in Iran, Iraq, Israel, Jordan, Kuwait, Oman, Qatar, KSA, and UAE [79] revealed the highest distribution of MERS-CoV in this area. Reeves and colleagues revealed a preliminary map of MERS-CoV; climatic dimensions of camel-associated cases are more constrained and less variable than the broader suite of MERS-CoV occurrences [80]. The latter findings reflected the importance of camel exposure as a key limiting factor for virus circulation.

\subsection{Distribution Pattern and Human Infections in Africa}

MERS-CoV antibodies have been reported in camels in various African countries including Burkina Faso, Egypt, Ethiopia, Kenya, Mali, Morocco, Nigeria, Senegal, Somalia, Sudan, Tunisia, and Uganda [54,66]. This emphasizes that MERS-CoV circulation among dromedaries in different geographical localities of Africa is extensive, and the viral shedding is as common as frequently reported in the Arabian Peninsula [54]. Despite this high prevalence of MERS-CoV in camels in Africa, the actual number of cases was relatively low including in Tunisia ( 3 cases), Algeria ( 2 cases), and Egypt (one case); all were travel related to the Arabian peninsula [78]. No index human cases were detected in Africa.

\subsection{Viral Invasion to Asia, Europe, and America}

Seropositive animals for MERS-CoV were reported in Asia (e.g., Bangladesh and Pakistan), Europe (e.g., Canary Islands, Spain), and Africa [45,59,60,68,69]. Nevertheless, all human cases reported in 
China, Thailand, Malaysia, Philippines, United Kingdom, Austria, Greece, the Netherlands, France, Germany, Italy, and the United States were imported via travelling from Middle East countries $[5,6]$.

In May 2015, an outbreak of MERS-CoV occurred in South Korea, resulting in a total of 186 human cases and a $19.35 \%$ mortality rate. The average age of Korean cases recorded were 55 years (ranging from 16 to 87 years), and $14 \%$ of cases in the South Korean outbreak were healthcare workers. The first case was an elderly male (68 years) who reported multiple travels to several countries of the Arabian Peninsula [74]. Later, MERS-CoVs were also reported in human cases from the Philippines (2 cases), Thailand ( 3 cases), China (one case), and Malaysia (2 cases) [78].

\subsection{Clusters of MERS-CoV Infections}

Despite the fact that the MERS-CoV was firstly reported in KSA in September 2012, CDC identified retrospectively MERS-CoV as the etiological agent responsible for two fatal cases of respiratory illness in Jordan in April 2012. Therefore, April 2012 is likely marked as the onset of the first MERS-CoV outbreak in humans [81,82]. Concurrently, in September 2012, another man from Qatar with a severe respiratory illness was admitted to a hospital unit in the United Kingdom. His case history revealed that he firstly developed illness in Qatar, traveled to KSA, and then to the UK for remediation $[77,83,84]$.

The first cluster of MERS-CoV infections was in November 2012 when a family contracted the virus in Riyadh, KSA. A total of 24 family members who had been in contact with the index case or with healthcare workers developed the illness, and two of the sick died [35].

The second cluster was retroactively reported in Jordan in 2012 and was related to the earliest confirmed two fatal cases (seven subjects including six healthcare workers) [81].

From 1st of April to 23rd of May 23, 2013, a total of 23 cases of MERS-CoV infections were reported in Al-Hasa governorate in the eastern province of KSA. Interestingly, a total of 21 of the 23 cases were acquired via person-to-person transmission in hemodialysis, in-patient, or intensive care units of three different healthcare facilities. Additionally, five laboratory-confirmed MERS-CoV cases were documented among 217 household and more than 200 healthcare workers [85] in the three different healthcare facilities, confirming that the person-to-person transmission of MERS-CoV can occur in healthcare settings and may be associated with considerable morbidity [85].

A patient infected with MERS-CoV with travel history to UAE was reported in France in May 2013. This patient shared a room in the hospital with another patient that became infected. The index case died and the second patient recovered [86].

MERS-CoV infections rapidly increased in KSA and the UAE during March and April 2014 [72,87]. Most of the cases were identified from outbreaks in hospitals in Riyadh, Jeddah, Madinah, and Tabuk in KSA, and in Al-Ain and Abu-Dhabi in the UAE. Cases included hospital workers, patients, visitors, and ambulance member staff. Asymptomatic or mild symptomatic infections were noticed in the majority of hospital workers but only $15 \%$ ended up with severe sickness or death [72]. The first case in the USA was reported in an American healthcare worker working in Riyadh, KSA. He went to Indiana in April 2014, and was admitted to the intensive care unit in the hospital [88]. The second reported case in the USA was diagnosed positive for MERS-CoV in May 2014 in Florida in an American citizen who had shortly returned from KSA [88,89].

The largest outbreak in South Korea started in May 2015 [75]. The first case was reported in a man who was on a journey in Bahrain, UAE, KSA, and Qatar [72,74]. Since May 2015, more than 180 associated cases were reported, including 36 deaths from both family members and hospital visitors [75]. Meanwhile, the first MERS-CoV case reported in China was in a Chinese man who traveled from South Korea to China [72,74].

\section{Impact of Comorbidities on MERS-CoV Infections in Humans}

Comorbidities such as asthma, diabetes mellitus, hypertension, ischemic heart disease, congestive heart failure, end-stage renal disease, and chronic kidney disease are known to weaken the host's innate and humoral immune systems and impair the production of proinflammatory cytokines, 
thereby limiting their ability to counteract any new infection [90]. Consequently, most fatalities have been documented in hospitalized patients with pre-existing comorbidities [91]. A systematic analysis of 637 MERS-CoV cases deduced that diabetes and hypertension are equally prevalent in approximately $50 \%$ of the patients. Cardiac diseases are present in $30 \%$ and obesity in $16 \%$ of the cases [92]. Statistically, the existence of underlying comorbidities was found to significantly complicate the infection with MERS-CoV, influence its severity, and significantly increase the overall fatality rates [93]. MERS patients of comparable age with comorbidities had approximately four times the risk for fatal infection as those without any comorbidity within the same epidemic period [94]. Additionally, the MERS-CoV DPP4 receptor is upregulated in the lungs of cigarette smokers and patients with chronic obstructive pulmonary disease (COPD), and this upregulation could explain why smokers and patients with comorbid lung diseases are more susceptible to MERS-CoV infection and are subject to severe MERS disease [95].

\section{Evolution of MERS-CoV}

Human CoVs (HCoVs) are of the alpha and beta genera of CoVs. MERS-CoV belongs to clade $\mathrm{C}$ of the beta-CoV genus [2,36]. Beta-CoVs, Tylonycteris bat virus (HKU4) and Pipistrellus bat virus (HKU5) are suggested as the closely-related species to MERS-CoV in clade C [96]. Additionally, a Neoromicia zuluensis bat virus was another related MERS-CoV in South Africa [97]. This highlighted the hypothesis that Pipistrellus and Neoromicia genera in the Vespertilionidae family were the reservoirs of MERS-CoV ancestors [34]. A rooted phylogenetic tree of MERS-CoV indicates that MERS-CoV first emerged in camels before zoonotic transmission to humans [34].

In this review, all available complete genomes were collected from the MERS-CoV database for human and camel isolates [98]. A rooted phylogenetic tree showed diverse MERS-CoV clades (Figure 2). MERS-CoV isolates were phylogenetically distinguished into three separate clades: A, B, and C. Clade A comprises the first EMC/human strain in KSA, Jordan-N3/2012 of 2012 and UAE camel strain $[4,99,100]$. MERS-CoV camel strains from Egypt, Morocco, Ethiopia, Burkina Faso, Nigeria, and Kenya were found in clade C $[14,55,101]$. The rest of human and camel strains mainly in the Arabian Peninsula and other countries with travel related to Arabia were sorted into clade B (Figure 2).

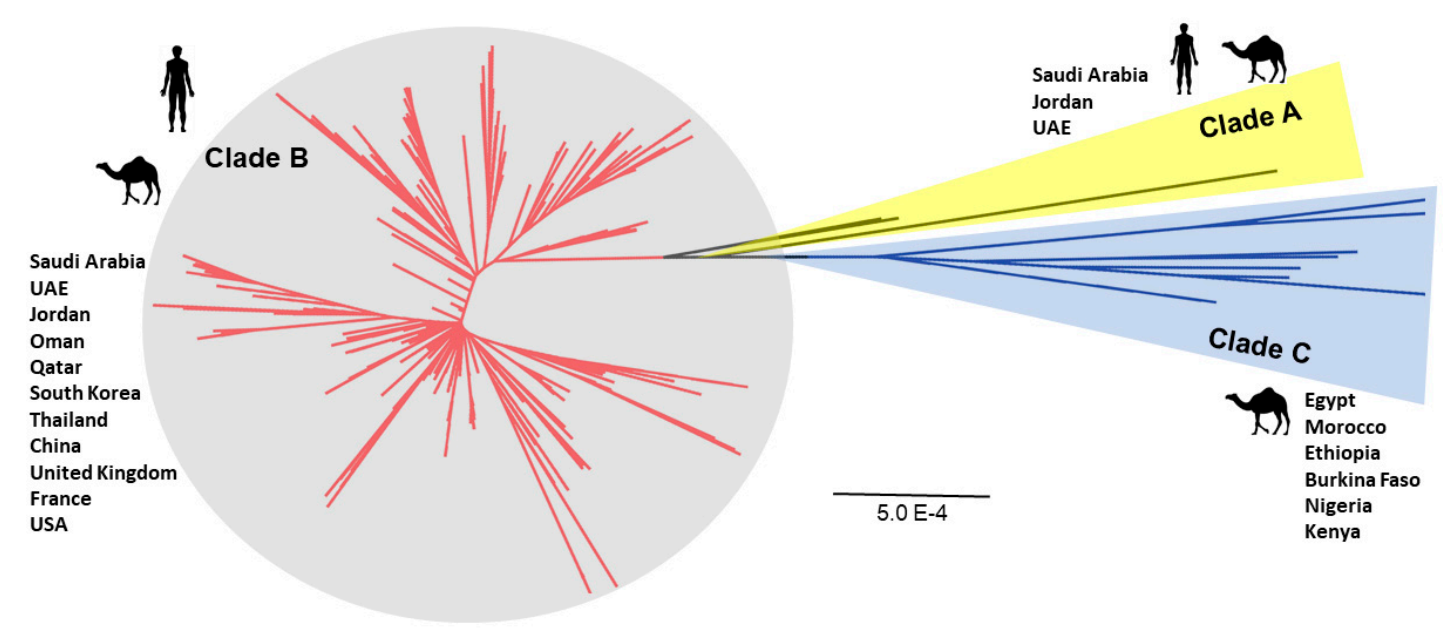

MERS-CoV complete genome tree

Figure 2. Three clades of MERS-CoV based on a rooted phylogenetic tree of 484 complete genomes of MERS-CoV strains from camel and human cases. MERS-CoV isolates are divided into three separate clades: A, B, and C. Clades A and B are prevalent in the Arabian Peninsula and other non-African world countries. Clade $C$ is mainly circulating in African countries. The optimal tree with the sum of branch length $=0.11869958$ is shown with scale bar $=0.0005(5.0 \mathrm{E}-4)$. 


\section{Mutation Patterns in Spike Protein of MERS-CoV}

The MERS-CoV genome is approximately $30.1 \mathrm{~kb}$ in size and generally encodes (1) structural spike (S), nucleocapsid (N), membrane (M), and envelope (E) proteins; and (2) nonstructural accessory (replicase (ORF1a and ORF1b), ORF 3, ORF 4a, ORF 4b, ORF 5) proteins (Figure 3a). The S protein is a glycosylated type I membrane protein that decorates the crown shape of the virion and functionally recognizes the cellular protein DPP4 via its receptor binding domain (RBD) to initiate viral entry into target cells.

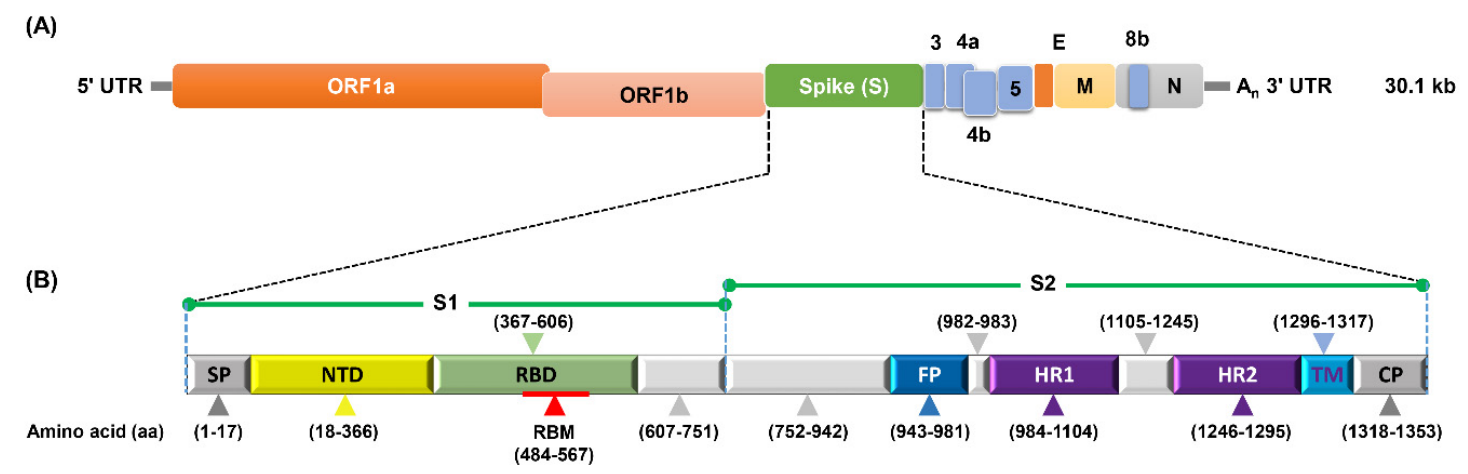

(c)

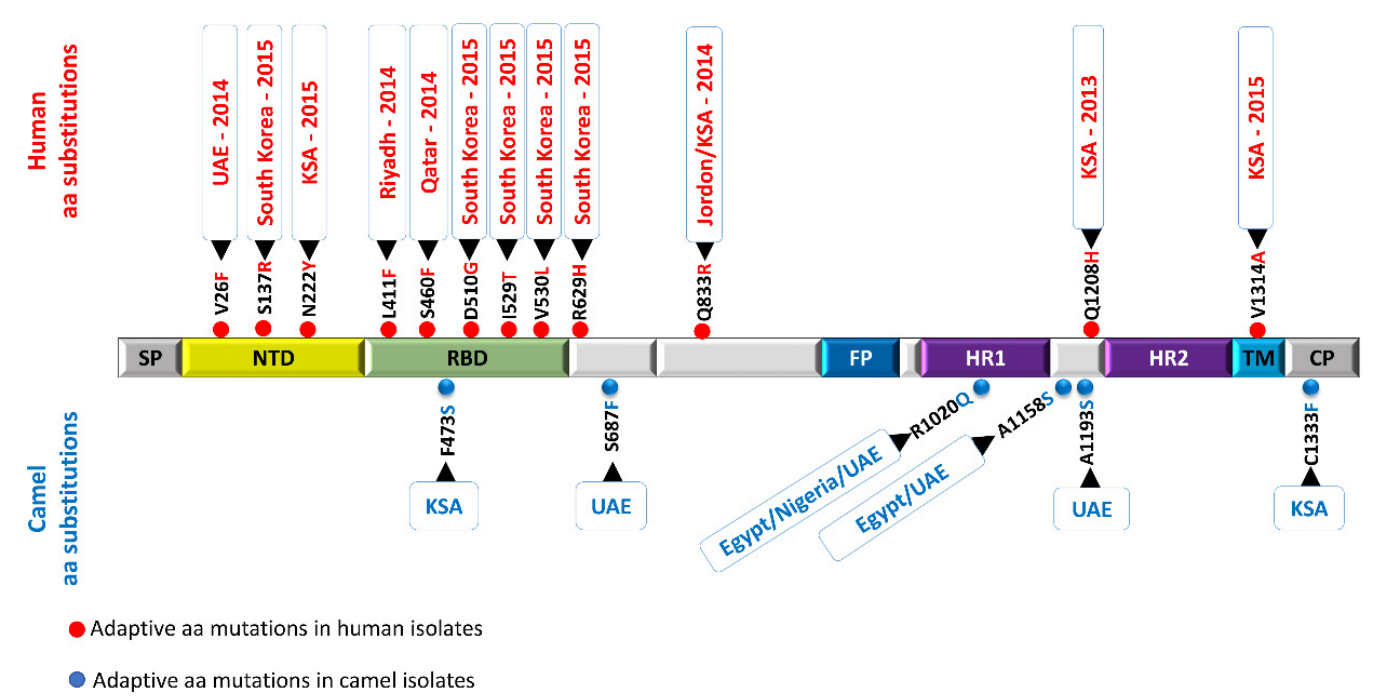

Figure 3. Schematic diagram of the MERS-CoV genome and naturally selected aa substitutions in spike protein. (A) The genomic structure of MERS-CoV (30.1 kb in length), illustrating sub-genomic viral RNA transcripts. (B) Schematic structure of the MERS-CoV S protein and its functional domains, including the N-terminal domain (NTD), receptor-binding domain (RBD), receptor-binding motif (RBM), fusion peptide (FP), heptad repeat region 1 and 2 (HR1 and HR2), transmembrane region (TM), and cytoplasmic tail (CP). (C) Since the first documentation of MERS-CoV in 2012 in KSA, the virus circulated in camels and occasionally humans to naturally acquire distinct adaptive amino acid (aa) substitutions.

The functional domain of MERS-CoV S protein comprises the N-terminal domain (NTD), receptor-binding domain (RBD), receptor-binding motif (RBM), fusion peptide (FP), heptad repeat region 1 and 2 (HR1 and HR2, respectively), transmembrane region (TM), and cytoplasmic tail (CP) (Figure $4 b$ ). The genetic alterations in the spike protein, especially in the RBD, may alter the virus transmissibility from one host to another. Consequently, following up the genetic and antigenic variations in the MERS-CoV spike protein is pivotal to recognize the molecular determinants of virus evolution and transmissibility. Moreover, recent studies have shown that several amino acid (aa) mutations were probably responsible for immune evasion of MERS-CoV [102]. During the outbreak in 
South Korea, the aa substitutions D510G and I529T in the RBD region were observed in most human MERS-CoV strains [103]. Evolution and transmission of MERS-CoV from bats to humans and camels may be acquired due to six mutations in the RBD region at sites Q419S, G436N, G472S, R479L, K511R, and G521N [104]. A lot of mutations in the spike protein were associated with major MERS-CoV outbreaks in KSA, UAE, and South Korea (Figure 3).

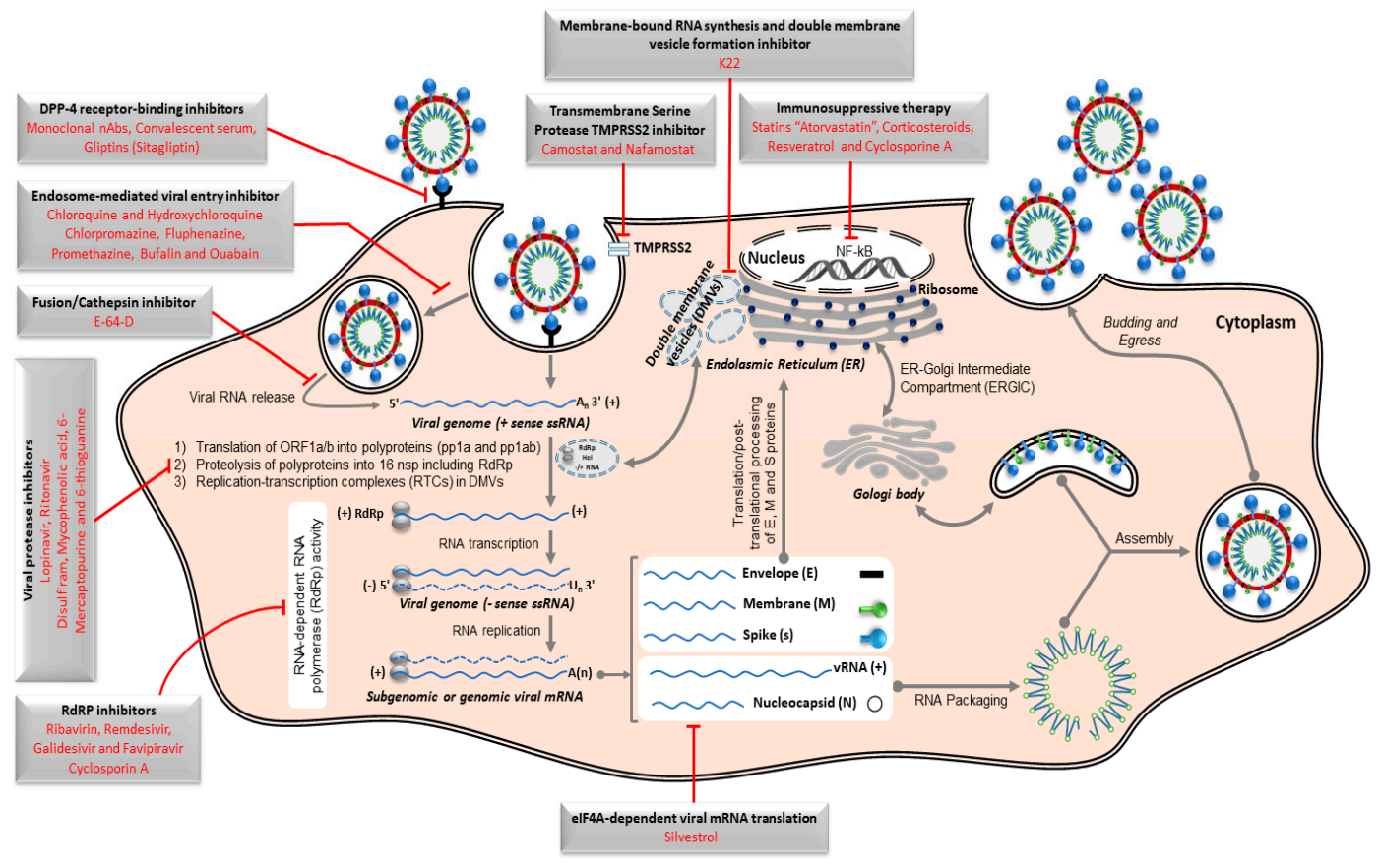

Figure 4. Schematic representation of Middle East respiratory syndrome coronavirus (MERS-CoV) replication cycle and key targets for antiviral activity. The spike protein of MERS-CoV initiates host cell infection via binding its receptor-binding domain (RBD) in the S1 subunit into cellular receptor dipeptidyl peptidase 4 (DPP4), originally known as the lymphocyte cell surface protein CD26. Following binding, the viral particle in the form of an endosome internalizes into the cytosol via acid-dependent proteolytic cleavage of S protein by a cathepsin or TMPRRS2. To release the viral genome (+ssRNA) into the cytoplasm, fusion of the viral and cellular membranes within acidified endosome occurs. Initially, the replicase gene, which encodes the largest two open-reading frames "ORF1a and ORF1ab", is translated to express two co-terminal polyproteins, pp1a and pp1ab. These polyproteins are further cleaved by virus-encoded proteases "papain-like protease PLpro and 3C-like protease 3CLpro" into 16 mature nonstructural proteins (nsp) including viral polymerase subunits. Essential elements for viral genome replication are gathered as RNA replication-transcription complexes (RTCs) within the endoplasmic reticulum-derived double-membrane vesicles (DMVs). The RTCs drive the production of intermediate negative-sense viral genome (-ssRNA) transcript. During replication, the -ssRNA genome is used as a template for generating nascent + ssRNA. Along with the continuous transcription to generate the nascent full-length coding +ssRNA, sub-genomic RNAs, including those encoding all essential structural proteins (spike (S), envelope (E), membrane (M), and nucleocapsid (N)), are produced via discontinuous transcription. Nucleocapsid and nascent genomic RNA are assembled together in the cytoplasm and further transported into the lumen of the endoplasmic reticulum (ER)-Golgi intermediate compartment (ERGIC). Meanwhile, the S, E, and M sub-genomic RNAs are translated and inserted into the membrane of the rough endoplasmic reticulum (ER), from where they are transported to interact with RNA-encapsidated N proteins in the ERGIC, forming a mature viral particle. Via exocytosis, the nascent viral particle is then released from the infected cell. The repurposed therapeutic drugs undergoing preclinical and clinical trials against MERS-CoV in the context of host pathways and virus replication mechanisms are represented in the figure. The symbol $\dashv$ refers to inhibition. 
For instance, the L411F substitution in the RBD region was found in strains from an outbreak in Riyadh, KSA in 2014 and in camel strains in Jeddah, KSA region [105]. S460F is unique in two human strains from Qatar. F473S is exclusively found in camel strains in Jeddah and Riyadh [105,106]. In the fusion peptide region, Q833R appeared in human Jeddah strains in 2014. V810I was prevalent in camel strains in the UAE, KSA, and Oman human cases [28]. In the N-terminal domain (NTD), V26A is a unique mutation found in camel strains of Egypt, Nigeria, and UAE in clade C, and V26F was found in human strains from Abu Dhabi, UAE in 2014 in clade B. H194Y was remarked in all clade A strains except in the EMC-human strain of 2012. N222Y was found in Buraydah, KSA human infections in 2015 in clade B. The contribution of these aa substitutions to alterations in receptor binding affinity, replication efficiency, and pathogenic significance has not yet been precisely evaluated and demands further effort to be investigated.

In the heptad repeat 1 (HR1) region, R1020Q marked camel strains in Egypt, Nigeria, UAE, and some KSA human strains in Jeddah [107,108]. A1193S in the region between HR1 and HR2 in the S2 fragment was predominant in clade B viruses that caused infections among healthcare workers in Abu Dhabi in 2014 [109]. A1158S was detected in camel strains in Egypt, UAE, and two human Jordanian cases. Q1208H also appeared as a unique mutation related to the Al-Hasa, KSA human outbreak in 2013 [12]. In the trans-membrane domain (TM) region, V1314A was observed in 2015 human cases in Riyadh, KSA in clade B. Additionally, C1333F in the cytoplasmic domain (CP) was observed in Jeddah camel strains through 2014 and 2015.

Other aa substitutions were documented to emerge during tissue-culture or mouse adaptation of MERS-CoV, and resulted in an improved replication efficiency in vitro and higher pathogenicity in vivo [110,111]. S746R and N762A are critical for bat-to-human transmission via mediated viral entry into human cells [110].

\section{Control Approaches for MERS-CoV}

\subsection{Antiviral Remedy}

Currently, no effective therapeutic interventions are approved or certified for treating the severe and acute infections with MERS-CoV or other coronaviruses. To rapidly identify potential therapeutic options against MERS-CoV, testing existing FDA licensed drugs for efficacy against novel viral pathogens represents a practical approach for antiviral screening (Figure 4). This could expedite the recommendation and/or implementation of those FDA approved drugs with effective anti-MERS-CoV activity in treatment protocols.

To date, numerous pharmaceutically active ingredients have shown potential for suppressing the replication of MERS-CoV in permissive Huh-7 and Vero-E6 cell lines. Those are currently applied as anti-diabetes mellitus type 2 inhibitors of DPP4 (such as sitagliptin), antibacterial agents (emetine dihydrochloride hydrate), antimalarial agents (chloroquine, hydroxychloroquine, amodiaquine, and mefloquine), antiparasitic agents (niclosamide and amodiaquine dihydrochloride dihydrate), antidiarrheal agent (loperamide), sterol metabolism inhibitor (triparanol), anti-cancer drugs (bufalin, imatinib, gemcitabine, and trametinib), protein-processing inhibitors (lopinavir, ritonavir, and disulfiram), neurotransmitter inhibitors (benztropine mesylate, fluspirilene, thiothixene, fluphenazine hydrochloride, promethazine hydrochloride, astemizole, chlorphenoxamine hydrochloride, chlorpromazine hydrochloride, thiethylperazine maleate, triflupromazine hydrochloride, and clomipramine hydrochloride), estrogen receptor antagonists (tamoxifen and toremifene citrate), kinase signaling inhibitors (imatinib mesylate, rapamycin, saracatinib, and dasatinib), and viral RNA-dependent RNA polymerase (RdRp) inhibitors (ribavirin, remdesivir, galidesivir, and favipiravir) [112-123].

In addition, severe MERS-CoV infections are likely associated with hyper-immune responses represented by the excessive production of inflammatory cytokines, chemokines, and interferon stimulated genes, namely cytokine storm (CS) [124]. To this point, immunosuppressants and 
inflammatory cytokines antagonists such as statins, (e.g., atorvastatin), resveratrol, and cyclosporine A are useful to minimize the consequences of CS, such as acute respiratory distress syndrome (ARDS) [121,125].

These several pharmaceutical classes of drugs were proven either in vitro or in vivo to be beneficial to control MERS-CoV infection. Most of these drugs appear to target host factors rather than viral proteins specifically [115]. Further studies should be applied to identify the non-viral targets of these drugs, providing a basis to discover new candidates for future research studies and clinical intervention protocols especially for newly emerging coronavirus infections such as pandemic SARS-CoV-2.

\subsection{Vaccination}

\subsubsection{Inactivated Vaccine}

The inactivated vaccine development process includes the propagation of the virus vaccine strain to appropriate titers followed by chemical or physical inactivation. This inactivated vaccine is widely applied and commercially traded to protect humans and domestic animals against many pathogens. It has several advantages including low production cost, high safety and stability, lack of post-formulation genetic modifications of candidate vaccine seed strains, and the enrichment of the inactivated vaccine with all viral cross-reactive antigens, which may contribute to improved viral immunogenicity. Contrarily, inactivated vaccine requires high biosafety containment level for virus propagation and antigen preparation, as well as suitable adjuvants to enhance immunogenicity [126]. Formaldehyde-inactivated whole MERS-CoV adjuvanted with Imject Alum induced specific neutralizing antibodies in vaccinated mice after two weeks post-vaccination that dramatically increased by eight weeks post-immunization, providing full neutralizing capacity [127]. Deng et al. showed that vaccinated mice with inactivated MERS-CoV with a combined adjuvant alum with CpG dinucleotides as a DNA vaccine adjuvant elicited a protective immune response during challenge infection in hDPP4 transgenic mice [128]. Moreover, an inactivated chimeric rabies virus displaying glycoprotein $(\mathrm{G})$ with spike protein subunit 1 (S1) protein of MERS-CoV induced robust neutralizing antibody responses against rabies and MERS-CoV [129]. Gamma irradiation $(\gamma)$-inactivated MERS-CoV vaccine evoked specific neutralizing antibodies and reduced viral titers in hDPP4 transgenic mice during challenge infection [130]. Mice vaccinated with $\gamma$-inactivated MERS-CoV vaccine developed lung mononuclear infiltrates with increased eosinophils promoting IL-5 and IL-13 cytokines, emphasizing that inactivated MERS-CoV vaccine can be accompanied with a hypersensitive-type lung pathology risk following challenge infection [131]. Recently, Shehata et al. generated a recombinant influenza A/H1N1 expressing chimeric neuraminidase protein with a short immunogenic peptide of MERS-CoV. This bivalent vaccine formulation induced potent and specific neutralizing antibodies against MERS-CoV in balb/c mice [132].

\subsubsection{Live-Attenuated Vaccine}

Live-attenuated vaccines are the most immunogenic and effective vaccines, even without supplementary adjuvant. Several methods were developed to generate candidate live-attenuated vaccine strains including genetically engineered low pathogenic vaccine strains using reverse genetic technology or virus attenuation by successive passaging of the candidate vaccine strain. However, live-attenuated vaccine has several limitations, including (1) the risk of reversion of the avirulent live-attenuated virus to its virulent phenotype during viral replication in the vaccinated host, (2) a necessity for a vaccine cold chain to maintain the vaccine potency, and (3) the inappropriateness of the vaccine for infants, immunocompromised individuals, and elderly people.

The first approach to develop a live-attenuated vaccine against MERS-CoV was achieved by deleting the structural E gene to produce a non-infectious recombinant MERS-CoV "rMERS-CoV $\Delta \mathrm{E}^{\prime \prime}$ virus. The developed rMERS-CoV $\Delta \mathrm{E}$ virus could only be grown in the laboratory by providing $\mathrm{E}$ protein in tran [133]. The rescued rMERS-CoV $\Delta \mathrm{E}$ virus, using reverse genetic technology based 
on bacterial artificial chromosome (BAC), allowed the generation of the first modified live vaccine candidate to protect against MERS-CoV [133]. In another study, a recombinant measles virus (MV) was used to express the full-length spike protein of MERS-CoV (MVvac2-CoV-S) [134]. The authors showed that the integration of the MERS-CoV spike protein into recombinant MV is genetically stable and induces strong neutralizing antibodies and cellular immunity against MERS-CoV in vaccinated hDPP4-transduced-mice [134].

Another approach to attenuate MERS-CoV was achieved through mutation of the highly conserved nonstructural protein 16 (NSP16) to lose its activity using reverse genetics [135]. The NSP16-deficient (dNSP16) MERS-CoV mutant became sensitive to type I interferon (IFN $\alpha / \beta)$, providing a clear attenuation mechanism of MERS CoV. The dNSP16 MERS-CoV mutant induced high levels of neutralizing antibodies and provided full protection against lethal MERS-CoV challenge in mice [135]. Live-attenuated bivalent recombinant MV expressing MERS-CoV N protein (MVvac2-MERS-N) induced robust and multifunctional $\mathrm{T}$ cell responses against MV and MERS CoV in an appropriate mouse model [136]. Comparing MVvac2-MERS-N and MVvac2-MERS-S vaccines indicated that MVvac2-CoV-S has a higher quality of cellular immune responses [136]. More recently, a live recombinant vesicular stomatitis virus (VSV) displaying the S protein of MERS-CoV instead of the $G$ protein induced both humoral and cell-mediated immunities in vaccinated rhesus macaques after a single dose of immunization [137]. More recently, Kato et al. developed a novel bivalent $\mathrm{RV} \triangle \mathrm{P}-\mathrm{MERS} / \mathrm{S} 1$ vaccine against rabies virus (RV) and MERS-CoV using a replication-incompetent $\mathrm{P}$-gene-deficient RV (RV $\Delta \mathrm{P})$ [138]. Using a reverse genetics method, the recombinant $\mathrm{RV} \Delta \mathrm{P}$ was used to express $\mathrm{S} 1$ fused to transmembrane and cytoplasmic domains together with 14 amino acids from the ectodomain of the RV-glycoprotein (RV-G). In RV $\Delta \mathrm{P}-\mathrm{MERS} / \mathrm{S} 1$ - and RV $\Delta \mathrm{P}$-vaccinated mice, there were no rabies-associated signs or symptoms. Serologically, RV $\triangle \mathrm{P}-\mathrm{MERS} / \mathrm{S} 1$ induced specific neutralizing antibodies against both MERS-CoV and RV following its intraperitoneal injection [138].

\subsubsection{Subunit Vaccine}

Among different types of vaccines, subunit vaccines have the highest safety profile in spite of their low immunogenicity [139]. Until now, the approaches to develop a subunit MERS-CoV vaccine were based on the adjuvanted full-length $\mathrm{S}, \mathrm{S} 1$, receptor-binding domain (RBD), or N-terminal domain (rNTD) of the $S$ protein. The RBD protein of MERS-CoV S is frequently recommended as a candidate antigen to develop MERS-CoV subunit vaccines. An adjuvanted "Montanide ISA 51" recombinant peptide comprising a 212-amino acid fragment (residues 377-588) of RBD (residues 367-606) of MERS-CoV spike protein fused with human IgG Fc fragment (S377-588-Fc) were able to induce strong MERS-CoV S-specific antibodies in vaccinated mice, enabling the binding of the RBD to DPP4 receptor and combating MERS-CoV infection via neutralization [140]. Among five different versions of RBD fragments fused with human IgG Fc, the form S377-588-Fc showed the highest DPP4-binding affinity and induced the highest titer of specific neutralizing IgG antibodies against MERS-CoV in vaccinated mice and New Zealand white rabbits [141]. Interestingly, an adjuvanted S377-588-Fc subunit vaccine elicited systemic humoral immune responses in mice vaccinated via intranasal and subcutaneous routes. Of note, stronger immune responses were observed in immunized mice via intranasal route than those injected subcutaneously [141]. The immunization of rabbits with the S358-588 S1-Fc fragment of RBD evoked specific neutralizing polyclonal antibodies against MERS-CoV [142]. Moreover, recombinant RBD fragment (S377-662) of S1 against (HCoV-EMC/2012) was shown to elicit high neutralizing antibodies in vaccinated mice [143]. In another study, the recombinant RBD fragment, S367-606, provided specific humoral and cellular immunity in BALB/c mice after vaccination [144]. Zhang et al. elucidated the effects of different adjuvants including Freund's adjuvant, alum, monophosphoryl lipid A, Montanide ISA51, and MF59 on the induction of host immune responses to a MERS-CoV RBD-based subunit vaccine, S377-588-Fc protein, as a model antigen. They demonstrated that the S377-588-Fc protein induced highly potent specific immune responses when formulated with MF59 adjuvant [145]. Mixing of multiple adjuvants together with the S377-588-Fc protein could synergistically improve the 
efficacy of the RBD-based subunit vaccine [146]. In line with this, Tai et al. showed that the recombinant trimeric RBD protein generated by fusing the RBD sequence (residues 377-588) with Fd trimerization motif induced protective neutralizing antibodies and protected hDPP4 transgenic mice from lethal MERS-CoV challenge [147]. Similarly, Pallesen et al. synthesized a recombinant pre-fusion trimeric MERS-CoV S protein to induce high titers of specific neutralizing antibodies in vaccinated BALB/c mice [148]. A robust neutralizing antibody response was elicited in BALB/c mice against MERS-CoV after immunization with purified full spike (S) protein nanoparticles (approximately $25 \mathrm{~nm}$ ) produced in SF9 cells infected with specific recombinant baculovirus expressing S protein [149]. In another trial by Jiaming et al., a recombinant rNTD was used as a potential subunit vaccine candidate to induce neutralizing antibodies, and it could reduce the respiratory tract pathology of immunized BALB/c mice in a non-lethal MERS-CoV challenge [150]. Another study showed that adjuvanted (MF59) MERS-CoV S1 protein protected vaccinated mice against lethal infection of MERS-CoV during challenge experiment, where the protection correlated well with the neutralizing antibody titer [151]. More recently, Adney et al. showed that vaccination with an adjuvanted MERS-CoV spike protein as a subunit vaccine provided complete protection against MERS-CoV infection in alpacas and resulted in reduced and delayed viral shedding in the upper airways of infected dromedary camels [152].

\subsubsection{Virus-Like Particle (VLP) Vaccine}

In general, the VLP vaccine is similar to the inactivated vaccine, but does not require the viral inactivation step which may alter the antigenicity and immunogenicity of a viral protein. Additionally, VLPs can be easily generated in a low-containment manufacturing environment due to the processing of pathogen-free materials [126]. A novel chimeric VLP vaccine displaying a fused canine parvovirus (CPV) VP2 structural protein with RBD of MERS-CoV induced specific humoral and cellular immune responses against MERS-CoV in vaccinated mice [153]. Additionally, Wang and his colleagues generated MERS-CoV VLPs by co-expressing structural S, E, and M proteins of MERS-CoV using the baculovirus expression system [154]. Electron microscopy demonstrated that the developed MERS-CoV VLPs were structurally similar to the native MERS-CoV virus [154]. Alum adjuvanted MERS-CoV VLPs induced high specific IgG antibody titers against the RBD and elicited cellular immunity in intramuscularly vaccinated rhesus macaques [154]. By using a baculovirus insect cell expression system to generate chimeric VLPs, S protein of MERS-CoV and matrix protein 1 (M1) of influenza A virus (IAV) were developed, showing high immunogenicity in mice when adjuvanted with alum and CpG ODN. The adjuvanted chimeric VLP vaccine elicited neutralizing antibody responses, while the actual protective efficacy of this chimeric VLP vaccine against MERS-CoV was not investigated in vivo [146].

\subsubsection{Viral Vector-Recombinant Vaccines}

Adenovirus, Newcastle disease virus (NDV), vesicular stomatitis virus (VSV), rabies virus (RABV), and modified vaccinia virus Ankara (MVA) were used as successful viral vectors in the development of MERS-CoV vaccines. Unlike inactivated and subunit vaccines, viral vector-recombinant vaccines do not require adjuvants to be immunogenic. Two recombinant human adenoviral vectors (rAd5 and rAd41) encoding the full-length $S$ protein showed neutralizing antibodies in immunized BALB/c mice [155]. The same study examined the effects of intramuscular or intragastric immunization route on immune responses using a single dose of rAd5 or rAd41 vectors encoding S of MERS $\mathrm{CoV}$. Intragastric administration of any recombinant adenoviral vaccine induced humoral immunity; however, cellular immune responses were not detected. In contrast, intramuscular administration of Ad5-S or Ad41-S induced both types of immunity [155]. Recombinant human adenoviral vector 5 (rAd5) encoding full S protein or shorter extracellular S1 domain of HCoV-EMC/2012 isolate induced antibody responses against MERS-CoV in vaccinated BALB/c mice [156]. A recent (2019) study by Hashem et al. revealed that the incorporation of CD40L into rAd5-based MERS-CoV S1 vaccine provided a complete protection to hDPP4 transgenic mice and prevented pulmonary perivascular hemorrhage post-viral challenge [157]. Chimpanzee adenovirus (ChAdOx1) has been used in the development of a 
viral vector vaccine against MERS-CoV. The recombinant (ChAdOx1 MERS) encoding full-length S protein of MERS CoV induced specific antibody response and offered complete protection to hDPP4 transgenic mice post-MERS-CoV viral challenge by only a single dose of intranasal or intramuscular immunization $[158,159]$. The recombinant (ChAdOx1 MERS) encoding full-length S vaccine was improved by insertion of a gene encoding the signal peptide of human tissue plasminogen activator (tPA) upstream of the S gene of MERS-CoV [158]. Chimpanzee adenovirus (ChAdOx1) containing the MERS-CoV S glycoprotein antigen has entered human clinical trials and is known as MERS001. This vaccine requires a one-time shot of $5 \times 109-5 \times 1010$ virus particles via the intramuscular route. The phase I clinical trial is sponsored by the University of Oxford, United Kingdom and is estimated to be completed by July 2021 (https://www.clinicaltrials.gov/ct2/show/record/NCT03399578).

Another recombinant viral vector for the development of a MERS CoV vaccine, vaccinia virus Ankara (MVA) encoding full length S protein, showed a good safety profile, immunogenicity, and high protective efficacy $[158,160]$. Volz and his colleagues developed a recombinant modified vaccinia virus expressing full S protein and immunized Ad5-hDPP4-transduced BALB/c mice. Results showed induction of humoral and cell-mediated immunity and neutralizing antibodies [161]. Another candidate vaccine currently in a phase I clinical trial is MVA-MERS-S (https://clinicaltrials.gov/ct2/show/ NCT03615911). The trial is being performed by the University Medical Center Hamburg-Eppendorf, Germany, in which the safety and immunogenicity of MVA-MERS-S in healthy adult volunteers are being assessed. Another study on Ad5-hDPP4-transduced BALB/c mice immunized with Venezuelan equine encephalitis virus replicon particles containing $S$ protein elucidated a reduction of viral titers to nearly undetectable levels after one day post infection and increased neutralizing antibody titers [162]. The vesicular stomatitis virus (VSV) used in a recent study as a viral vector for the spike gene of MERS-CoV formulating chimeric virus called (VSV $\Delta$ G-MERS) induced immunological T-cell response and virus neutralization in a rhesus monkey model against VSV and MERS-CoV with a single immunization dose [137]. The NDV displaying MERS-CoV S protein vaccine induced neutralizing antibodies in BALB/c mice and Bactrian camels [163].

\subsubsection{DNA Vaccine}

DNA encoding the full-length $S$ protein was shown to induce neutralizing antibodies and robust cell-mediated immunity in immunized mice, macaques, and camels [164]. Wang et al. developed two candidate vaccines, namely a subunit (full S and S1 protein fraction) and a DNA vaccine (full S and S1 gene in a mammalian VRC8400 vector), which were used to immunize female BALB/c mice and Indian rhesus macaques [151]. Results showed that of the eight vaccine regimens, the full S DNA (plus electroporation) and S1 protein vaccines elicited high titers of neutralizing antibodies in mice against different strains of MERS-CoV. Three vaccine regimens that were more immunogenic in mice were selected to be evaluated in the rhesus macaque model. The full S DNA and S1 protein yielded potent $\mathrm{nAb}$ titers in sera of rhesus macaques. Additionally, the DNA-primed regimen induced earlier protection from pneumonia and clearance of lung infiltrates in rhesus macaques due to induction of effector CD8 + T cells [151]. Other researchers showed that immunization of mice with a DNA vaccine encoding the $\mathrm{S} 1$ domain and passive immune sera protected hDPP4-transgenic-mice from MERS-CoV infection [165]. The DNA vaccine having partial S showed more immunogenicity than full-length S; however, both DNAs encoding the S1 and S proteins were shown to induce neutralizing antibodies that cross-reacted with MERS-CoV strains of human and camel origins [166].

\section{Conclusions and Perspectives}

MERS Coronavirus continues to circulate and infect human species constituting a significant threat with a fatality rate higher than SARS-COV-2. Herein, we summarized the current scientific knowledge about MERS-CoV covering virological, epidemiological, and therapeutic intervention aspects. To our knowledge, MERS-CoV is well-maintained in dromedary camels, resulting in asymptomatic to benign illness. Dromedary camels serve as a major reservoir of the virus with silent spillover human infections. 
Although dromedary camels are well-known to be the main reservoir of the virus, the origin of the virus and how it was introduced into camels, whether direct or indirect transmission from bats, is not very well understood. Additionally, in the KSA, which comprises $84 \%$ of the globally reported cases and $91 \%$ of the overall global fatalities, up to $50 \%$ of MERS-CoV cases occurred via human-to-human transmission through close contact with asymptomatic or symptomatic individuals infected with MERS-CoV in household or health-care settings. So far, there are no specific drugs or vaccines against MERS disease. Therefore, intensive screening for novel antiviral agents and effective vaccines against MERS-CoV is clearly an urgent need. Finally, MERS is a prime example of a zoonotic disease, and this emphasizes the relevance of a "one health" approach, where efforts of experts in animal health, human health, research, ecology, and epidemiology should come together to control MERS-CoV infections.

Author Contributions: A.M., A.K., M.S., G.K. and M.A.A., conceived and co-wrote the initial version of the manuscript. R.E.S. and A.M.S., assisted in the completion and reviewing of the manuscript. All authors contributed to the careful evaluation of the manuscript before submission. All authors have read the revised version of the manuscript and agreed to the published version of the manuscript.

Funding: This work was funded by the National Institute of Allergy and Infectious Diseases, National Institutes of Health, US Department of Health and Human Services (under contract HHSN272201400006C).

Acknowledgments: The authors gratefully acknowledge Rebecca Badra for her assistance in reviewing the manuscript.

Conflicts of Interest: The authors declare no conflict of interest. The funders had no role in the design of the study; in the collection, analyses, or interpretation of data; in the writing of the manuscript, or in the decision to publish the results.

\section{References}

1. Gonzalez, J.M.; Gomez-Puertas, P.; Cavanagh, D.; Gorbalenya, A.E.; Enjuanes, L. A comparative sequence analysis to revise the current taxonomy of the family Coronaviridae. Arch. Virol. 2003, 148, 2207-2235. [CrossRef] [PubMed]

2. ICTV. ICTV Taxonomy History for Coronavirinae Virus Taxonomy: 2011 Release. Available online: http://www.ictvonline.org/virusTaxonomy.asp?taxnode_id=20110624 (accessed on 20 August 2014).

3. Perlman, S.; Netland, J. Coronaviruses post-SARS: Update on replication and pathogenesis. Nat. Rev. Microbiol. 2009, 7, 439-450. [CrossRef] [PubMed]

4. Zaki, A.M.; van Boheemen, S.; Bestebroer, T.M.; Osterhaus, A.D.; Fouchier, R.A. Isolation of a novel coronavirus from a man with pneumonia in Saudi Arabia. N. Engl. J. Med. 2012, 367, 1814-1820. [CrossRef]

5. FAO. MERS-CoV Situation Update. Available online: http://www.fao.org/ag/againfo/programmes/en/empres/ mers/situation_update.html (accessed on 30 June 2020).

6. WHO. Middle East respiratory Syndrome Coronavirus (MERS-CoV): MERS Monthly Summary, September 2019. Available online: https://www.who.int/emergencies/mers-cov/en/ (accessed on 30 June 2020).

7. Gulland, A. WHO voices concern over rising numbers of MERS-CoV cases. BMJ 2014, 348, g2968. [CrossRef] [PubMed]

8. Memish, Z.A.; Assiri, A.; Alhakeem, R.; Yezli, S.; Almasri, M.; Zumla, A.; Al-Tawfiq, J.A.; Drosten, C.; Albarrak, A.; Petersen, E. Middle East respiratory syndrome corona virus, MERS-CoV. Conclusions from the 2nd scientific advisory board meeting of the WHO collaborating center for mass gathering medicine, Riyadh. Int. J. Infect. Dis. IJID Off. Publ. Int. Soc. Infect. Dis. 2014, 24, 51-53. [CrossRef]

9. Drosten, C.; Gunther, S.; Preiser, W.; van der Werf, S.; Brodt, H.R.; Becker, S.; Rabenau, H.; Panning, M.; Kolesnikova, L.; Fouchier, R.A.; et al. Identification of a novel coronavirus in patients with severe acute respiratory syndrome. N. Engl. J. Med. 2003, 348, 1967-1976. [CrossRef] [PubMed]

10. Cunha, C.B.; Opal, S.M. Middle East respiratory syndrome (MERS): A new zoonotic viral pneumonia. Virulence 2014, 5, 650-654. [CrossRef]

11. Shehata, M.M.; Gomaa, M.R.; Ali, M.A.; Kayali, G. Middle East respiratory syndrome coronavirus: A comprehensive review. Front. Med. 2016, 10, 120-136. [CrossRef] 
12. Cotten, M.; Watson, S.J.; Kellam, P.; Al-Rabeeah, A.A.; Makhdoom, H.Q.; Assiri, A.; Al-Tawfiq, J.A.; Alhakeem, R.F.; Madani, H.; AlRabiah, F.A.; et al. Transmission and evolution of the Middle East respiratory syndrome coronavirus in Saudi Arabia: A descriptive genomic study. Lancet 2013, 382, 1993-2002. [CrossRef]

13. Chu, D.K.; Poon, L.L.; Gomaa, M.M.; Shehata, M.M.; Perera, R.A.; Abu Zeid, D.; El Rifay, A.S.; Siu, L.Y.; Guan, Y.; Webby, R.J.; et al. MERS coronaviruses in dromedary camels, Egypt. Emerg. Infect. Dis. 2014, 20, 1049-1053. [CrossRef]

14. Chu, D.K.W.; Hui, K.P.Y.; Perera, R.; Miguel, E.; Niemeyer, D.; Zhao, J.; Channappanavar, R.; Dudas, G.; Oladipo, J.O.; Traore, A.; et al. MERS coronaviruses from camels in Africa exhibit region-dependent genetic diversity. Proc. Natl. Acad. Sci. USA 2018, 115, 3144-3149. [CrossRef] [PubMed]

15. Eckerle, I.; Ehlen, L.; Kallies, R.; Wollny, R.; Corman, V.M.; Cottontail, V.M.; Tschapka, M.; Oppong, S.; Drosten, C.; Muller, M.A. Bat airway epithelial cells: A novel tool for the study of zoonotic viruses. PLoS ONE 2014, 9, e84679. [CrossRef] [PubMed]

16. Memish, Z.A.; Mishra, N.; Olival, K.J.; Fagbo, S.F.; Kapoor, V.; Epstein, J.H.; Alhakeem, R.; Durosinloun, A.; Al Asmari, M.; Islam, A.; et al. Middle East respiratory syndrome coronavirus in bats, Saudi Arabia. Emerg. Infect. Dis. 2013, 19, 1819-1823. [CrossRef] [PubMed]

17. Annan, A.; Baldwin, H.J.; Corman, V.M.; Klose, S.M.; Owusu, M.; Nkrumah, E.E.; Badu, E.K.; Anti, P.; Agbenyega, O.; Meyer, B.; et al. Human betacoronavirus 2c EMC/2012-related viruses in bats, Ghana and Europe. Emerg. Infect. Dis. 2013, 19, 456-459. [CrossRef]

18. Anthony, S.J.; Ojeda-Flores, R.; Rico-Chavez, O.; Navarrete-Macias, I.; Zambrana-Torrelio, C.M.; Rostal, M.K.; Epstein, J.H.; Tipps, T.; Liang, E.; Sanchez-Leon, M.; et al. Coronaviruses in bats from Mexico. J. Gen. Virol. 2013, 94, 1028-1038. [CrossRef]

19. Yang, L.; Wu, Z.; Ren, X.; Yang, F.; Zhang, J.; He, G.; Dong, J.; Sun, L.; Zhu, Y.; Zhang, S.; et al. MERS-related betacoronavirus in Vespertilio superans bats, China. Emerg. Infect. Dis. 2014, 20. [CrossRef]

20. Azhar, E.I.; Hashem, A.M.; El-Kafrawy, S.A.; Sohrab, S.S.; Aburizaiza, A.S.; Farraj, S.A.; Hassan, A.M.; Al-Saeed, M.S.; Jamjoom, G.A.; Madani, T.A. Detection of the middle East respiratory syndrome coronavirus genome in an air sample originating from a camel barn owned by an infected patient. mBio 2014, 5. [CrossRef]

21. Corman, V.M.; Jores, J.; Meyer, B.; Younan, M.; Liljander, A.; Said, M.Y.; Gluecks, I.; Lattwein, E.; Bosch, B.J.; Drexler, J.F.; et al. Antibodies against MERS coronavirus in dromedary camels, Kenya, 1992-2013. Emerg. Infect. Dis. 2014, 20. [CrossRef]

22. Hemida, M.G.; Perera, R.A.; Wang, P.; Alhammadi, M.A.; Siu, L.Y.; Li, M.; Poon, L.L.; Saif, L.; Alnaeem, A.; Peiris, M. Middle East Respiratory Syndrome (MERS) coronavirus seroprevalence in domestic livestock in Saudi Arabia, 2010 to 2013. Eurosurveillance 2013, 18, 20659. [CrossRef]

23. Reusken, C.B.; Messadi, L.; Feyisa, A.; Ularamu, H.; Godeke, G.J.; Danmarwa, A.; Dawo, F.; Jemli, M.; Melaku, S.; Shamaki, D.; et al. Geographic distribution of MERS coronavirus among dromedary camels, Africa. Emerg. Infect. Dis. 2014, 20, 1370-1374. [CrossRef]

24. Nowotny, N.; Kolodziejek, J. Middle East respiratory syndrome coronavirus (MERS-CoV) in dromedary camels, Oman, 2013. Eurosurveillance 2014, 19, 20781. [CrossRef] [PubMed]

25. Meyer, B.; Muller, M.A.; Corman, V.M.; Reusken, C.B.; Ritz, D.; Godeke, G.J.; Lattwein, E.; Kallies, S.; Siemens, A.; van Beek, J.; et al. Antibodies against MERS coronavirus in dromedary camels, United Arab Emirates, 2003 and 2013. Emerg. Infect. Dis. 2014, 20, 552-559. [CrossRef] [PubMed]

26. Hemida, M.; Perera, R.; Al Jassim, R.; Kayali, G.; Siu, L.; Wang, P.; Chu, K.; Perlman, S.; Ali, M.; Alnaeem, A.; et al. Seroepidemiology of Middle East respiratory syndrome (MERS) coronavirus in Saudi Arabia (1993) and Australia (2014) and characterisation of assay specificity. Eurosurveillance 2014, 19, 20828. [CrossRef] [PubMed]

27. Raj, V.S.; Farag, E.A.; Reusken, C.B.; Lamers, M.M.; Pas, S.D.; Voermans, J.; Smits, S.L.; Osterhaus, A.D.; Al-Mawlawi, N.; Al-Romaihi, H.E.; et al. Isolation of MERS coronavirus from a dromedary camel, Qatar, 2014. Emerg. Infect. Dis. 2014, 20. [CrossRef]

28. Hemida, M.G.; Chu, D.K.; Poon, L.L.; Perera, R.A.; Alhammadi, M.A.; Ng, H.Y.; Siu, L.Y.; Guan, Y.; Alnaeem, A.; Peiris, M. MERS coronavirus in dromedary camel herd, Saudi Arabia. Emerg. Infect. Dis. 2014, 20. [CrossRef] 
29. Perera, R.A.; Wang, P.; Gomaa, M.R.; El-Shesheny, R.; Kandeil, A.; Bagato, O.; Siu, L.Y.; Shehata, M.M.; Kayed, A.S.; Moatasim, Y.; et al. Seroepidemiology for MERS coronavirus using microneutralisation and pseudoparticle virus neutralisation assays reveal a high prevalence of antibody in dromedary camels in Egypt, June 2013. Eurosurveillance 2013, 18, 20574. [CrossRef]

30. Reusken, C.B.; Ababneh, M.; Raj, V.S.; Meyer, B.; Eljarah, A.; Abutarbush, S.; Godeke, G.J.; Bestebroer, T.M.; Zutt, I.; Muller, M.A.; et al. Middle East Respiratory Syndrome coronavirus (MERS-CoV) serology in major livestock species in an affected region in Jordan, June to September 2013. Eurosurveillance 2013, 18, 20662. [CrossRef]

31. Harcourt, J.L.; Rudoler, N.; Tamin, A.; Leshem, E.; Rasis, M.; Giladi, M.; Haynes, L.M. The prevalence of Middle East respiratory syndrome coronavirus (MERS-CoV) antibodies in dromedary camels in Israel. Zoonoses Public Health 2018. [CrossRef]

32. Gardner, E.G.; Kiambi, S.; Sitawa, R.; Kelton, D.; Kimutai, J.; Poljak, Z.; Tadesse, Z.; Von Dobschuetz, S.; Wiersma, L.; Greer, A.L. Force of infection of Middle East respiratory syndrome in dromedary camels in Kenya. Epidemiol. Infect. 2019, 147, e275. [CrossRef]

33. Cha, R.-H.; Joh, J.-S.; Jeong, I.; Lee, J.Y.; Shin, H.-S.; Kim, G.; Kim, Y.; Critical Care Team of National Medical Center. Renal complications and their prognosis in Korean patients with Middle East respiratory syndrome-coronavirus from the central MERS-CoV designated hospital. J. Korean Med. Sci. 2015, 30, 1807-1814. [CrossRef]

34. Corman, V.M.; Ithete, N.L.; Richards, L.R.; Schoeman, M.C.; Preiser, W.; Drosten, C.; Drexler, J.F. Rooting the phylogenetic tree of middle East respiratory syndrome coronavirus by characterization of a conspecific virus from an African bat. J. Virol. 2014, 88, 11297-11303. [CrossRef] [PubMed]

35. Memish, Z.A.; Zumla, A.I.; Assiri, A. Middle East respiratory syndrome coronavirus infections in health care workers. N. Engl. J. Med. 2013, 369, 884-886. [CrossRef] [PubMed]

36. van Boheemen, S.; de Graaf, M.; Lauber, C.; Bestebroer, T.M.; Raj, V.S.; Zaki, A.M.; Osterhaus, A.D.; Haagmans, B.L.; Gorbalenya, A.E.; Snijder, E.J.; et al. Genomic characterization of a newly discovered coronavirus associated with acute respiratory distress syndrome in humans. mBio 2012, 3. [CrossRef] [PubMed]

37. Woo, P.C.; Lau, S.K.; Lam, C.S.; Lau, C.C.; Tsang, A.K.; Lau, J.H.; Bai, R.; Teng, J.L.; Tsang, C.C.; Wang, M.; et al. Discovery of seven novel Mammalian and avian coronaviruses in the genus deltacoronavirus supports bat coronaviruses as the gene source of alphacoronavirus and betacoronavirus and avian coronaviruses as the gene source of gammacoronavirus and deltacoronavirus. J. Virol. 2012, 86, 3995-4008. [CrossRef] [PubMed]

38. Gierer, S.; Hofmann-Winkler, H.; Albuali, W.H.; Bertram, S.; Al-Rubaish, A.M.; Yousef, A.A.; Al-Nafaie, A.N.; Al-Ali, A.K.; Obeid, O.E.; Alkharsah, K.R.; et al. Lack of MERS coronavirus neutralizing antibodies in humans, eastern province, Saudi Arabia. Emerg. Infect. Dis. 2013, 19, 2034-2036. [CrossRef] [PubMed]

39. Aburizaiza, A.S.; Mattes, F.M.; Azhar, E.I.; Hassan, A.M.; Memish, Z.A.; Muth, D.; Meyer, B.; Lattwein, E.; Muller, M.A.; Drosten, C. Investigation of anti-middle East respiratory syndrome antibodies in blood donors and slaughterhouse workers in Jeddah and Makkah, Saudi Arabia, fall 2012. J. Infect. Dis. 2014, 209, 243-246. [CrossRef]

40. Muller, M.A.; Meyer, B.; Corman, V.M.; Al-Masri, M.; Turkestani, A.; Ritz, D.; Sieberg, A.; Aldabbagh, S.; Bosch, B.J.; Lattwein, E.; et al. Presence of Middle East respiratory syndrome coronavirus antibodies in Saudi Arabia: A nationwide, cross-sectional, serological study. Lancet Infect. Dis. 2015, 15, 629. [CrossRef]

41. Reusken, C.B.; Farag, E.A.; Haagmans, B.L.; Mohran, K.A.; Godeke, G.J.t.; Raj, S.; Alhajri, F.; Al-Marri, S.A.; Al-Romaihi, H.E.; Al-Thani, M.; et al. Occupational exposure to dromedaries and risk for MERS-CoV infection, Qatar, 2013-2014. Emerg. Infect. Dis. 2015, 21, 1422-1425. [CrossRef]

42. Memish, Z.A.; Almasri, M.; Turkestani, A.; Al-Shangiti, A.M.; Yezli, S. Etiology of severe community-acquired pneumonia during the 2013 Hajj-part of the MERS-CoV surveillance program. Int. J. Infect. Dis. Ijid Off. Publ. Int. Soc. Infect. Dis. 2014, 25, 186-190. [CrossRef]

43. Kandeil, A.; Gomaa, M.; Shehata, M.; El-Taweel, A.; Kayed, A.E.; Abiadh, A.; Jrijer, J.; Moatasim, Y.; Kutkat, O.; Bagato, O.; et al. Middle East respiratory syndrome coronavirus infection in non-camelid domestic mammals. Emerg. Microbes Infect. 2019, 8, 103-108. [CrossRef] 
44. Gikonyo, S.; Kimani, T.; Matere, J.; Kimutai, J.; Kiambi, S.G.; Bitek, A.O.; Juma Ngeiywa, K.J.Z.; Makonnen, Y.J.; Tripodi, A.; Morzaria, S.; et al. Mapping potential amplification and transmission hotspots for MERS-CoV, Kenya. EcoHealth 2018. [CrossRef] [PubMed]

45. Ali, M.A.; Shehata, M.M.; Gomaa, M.R.; Kandeil, A.; El-Shesheny, R.; Kayed, A.S.; El-Taweel, A.N.; Atea, M.; Hassan, N.; Bagato, O.; et al. Systematic, active surveillance for Middle East respiratory syndrome coronavirus in camels in Egypt. Emerg. Microbes Infect. 2017, 6, e1. [CrossRef]

46. Reusken, C.B.; Haagmans, B.L.; Muller, M.A.; Gutierrez, C.; Godeke, G.J.; Meyer, B.; Muth, D.; Raj, V.S.; Smits-De Vries, L.; Corman, V.M.; et al. Middle East respiratory syndrome coronavirus neutralising serum antibodies in dromedary camels: A comparative serological study. Lancet Infect. Dis. 2013, 13, 859-866. [CrossRef]

47. Reusken, C.; Farag, E.; Jonges, M.; Godeke, G.; El-Sayed, A.; Pas, S.; Raj, V.; Mohran, K.; Moussa, H.; Ghobashy, H.; et al. Middle East respiratory syndrome coronavirus (MERS-CoV) RNA and neutralising antibodies in milk collected according to local customs from dromedary camels, Qatar, April 2014. Eurosurveillance 2014, 19, 20829. [CrossRef] [PubMed]

48. Muller, M.A.; Corman, V.M.; Jores, J.; Meyer, B.; Younan, M.; Liljander, A.; Bosch, B.J.; Lattwein, E.; Hilali, M.; Musa, B.E.; et al. MERS coronavirus neutralizing antibodies in camels, Eastern Africa, 1983-1997. Emerg. Infect. Dis. 2014, 20, 2093-2095. [CrossRef] [PubMed]

49. Azhar, E.I.; El-Kafrawy, S.A.; Farraj, S.A.; Hassan, A.M.; Al-Saeed, M.S.; Hashem, A.M.; Madani, T.A. Evidence for camel-to-human transmission of MERS coronavirus. N. Engl. J. Med. 2014, 370, $2499-2505$. [CrossRef] [PubMed]

50. Haagmans, B.L.; Al Dhahiry, S.H.; Reusken, C.B.; Raj, V.S.; Galiano, M.; Myers, R.; Godeke, G.J.; Jonges, M.; Farag, E.; Diab, A.; et al. Middle East respiratory syndrome coronavirus in dromedary camels: An outbreak investigation. Lancet Infect. Dis. 2014, 14, 140-145. [CrossRef]

51. Alagaili, A.N.; Briese, T.; Mishra, N.; Kapoor, V.; Sameroff, S.C.; Burbelo, P.D.; de Wit, E.; Munster, V.J.; Hensley, L.E.; Zalmout, I.S.; et al. Middle East respiratory syndrome coronavirus infection in dromedary camels in Saudi Arabia. mBio 2014, 5, e00884-14. [CrossRef]

52. Adney, D.R.; van Doremalen, N.; Brown, V.R.; Bushmaker, T.; Scott, D.; de Wit, E.; Bowen, R.A.; Munster, V.J. Replication and shedding of MERS-CoV in upper respiratory tract of inoculated dromedary camels. Emerg. Infect. Dis. 2014, 20, 1999-2005. [CrossRef]

53. Widagdo, W.; Raj, V.S.; Schipper, D.; Kolijn, K.; van Leenders, G.J.L.H.; Bosch, B.J.; Bensaid, A.; Segalés, J.; Baumgärtner, W.; Osterhaus, A.D.M.E.; et al. Differential expression of the Middle East respiratory syndrome coronavirus receptor in the upper respiratory tracts of humans and dromedary camels. J. Virol. 2016, 90, 4838-4842. [CrossRef]

54. Kandeil, A.; Gomaa, M.; Nageh, A.; Shehata, M.M.; Kayed, A.E.; Sabir, J.S.M.; Abiadh, A.; Jrijer, J.; Amr, Z.; Said, M.A.; et al. Middle East respiratory syndrome coronavirus (MERS-CoV) in dromedary camels in Africa and Middle East. Viruses 2019, 11, 717. [CrossRef]

55. Reusken, C.B.; Raj, V.S.; Koopmans, M.P.; Haagmans, B.L. Cross host transmission in the emergence of MERS coronavirus. Curr. Opin. Virol. 2016, 16, 55-62. [CrossRef] [PubMed]

56. Khalafalla, A.I.; Lu, X.; Al-Mubarak, A.I.A.; Dalab, A.H.S.; Al-Busadah, K.A.S.; Erdman, D.D. MERS-CoV in upper respiratory tract and lungs of dromedary camels, Saudi Arabia, 2013-2014. Emerg. Infect. Dis. 2015, 21, 1153-1158. [CrossRef] [PubMed]

57. Chan, S.M.; Damdinjav, B.; Perera, R.A.; Chu, D.K.; Khishgee, B.; Enkhbold, B.; Poon, L.L.; Peiris, M. Absence of MERS-Coronavirus in bactrian camels, Southern Mongolia, November 2014. Emerg. Infect. Dis. 2015, 21, 1269-1271. [CrossRef]

58. Ali, M.; El-Shesheny, R.; Kandeil, A.; Shehata, M.; Elsokary, B.; Gomaa, M.; Hassan, N.; El Sayed, A.; El-Taweel, A.; Sobhy, H.; et al. Cross-sectional surveillance of Middle East respiratory syndrome coronavirus (MERS-CoV) in dromedary camels and other mammals in Egypt, August 2015 to January 2016. Eurosurveillance 2017, 22. [CrossRef] [PubMed]

59. Islam, A.; Epstein, J.H.; Rostal, M.K.; Islam, S.; Rahman, M.Z.; Hossain, M.E.; Uzzaman, M.S.; Munster, V.J.; Peiris, M.; Flora, M.S.; et al. Middle East Respiratory Syndrome Coronavirus Antibodies in Dromedary Camels, Bangladesh, 2015. Emerg. Infect. Dis. 2018, 24, 926-928. [CrossRef] 
60. Gutiérrez, C.; Tejedor-Junco, M.T.; González, M.; Lattwein, E.; Renneker, S. Presence of antibodies but no evidence for circulation of MERS-CoV in dromedaries on the Canary Islands, 2015. Eurosurveillance 2015, 20, 30019. [CrossRef]

61. David, D.; Rotenberg, D.; Khinich, E.; Erster, O.; Bardenstein, S.; van Straten, M.; Okba, N.M.A.; Raj, S.V.; Haagmans, B.L.; Miculitzki, M.; et al. Middle East respiratory syndrome coronavirus specific antibodies in naturally exposed Israeli llamas, alpacas and camels. One Health 2018, 5, 65-68. [CrossRef]

62. Falzarano, D.; Kamissoko, B.; de Wit, E.; Maiga, O.; Cronin, J.; Samake, K.; Traore, A.; Milne-Price, S.; Munster, V.J.; Sogoba, N.; et al. Dromedary camels in northern Mali have high seropositivity to MERS-CoV. One Health 2017, 3, 41-43. [CrossRef]

63. Memish, Z.A.; Al-Tawfiq, J.A.; Assiri, A.; AlRabiah, F.A.; Al Hajjar, S.; Albarrak, A.; Flemban, H.; Alhakeem, R.F.; Makhdoom, H.Q.; Alsubaie, S.; et al. Middle East respiratory syndrome coronavirus disease in children. Pediatric Infect. Dis. J. 2014, 33, 904-906. [CrossRef]

64. Harrath, R.; Abu Duhier, F.M. Sero-prevalence of Middle East respiratory syndrome coronavirus (MERS-CoV) specific antibodies in dromedary camels in Tabuk, Saudi Arabia. J. Med. Virol. 2018, 90, 1285-1289. [CrossRef] [PubMed]

65. Alexandersen, S.; Kobinger, G.P.; Soule, G.; Wernery, U. Middle East respiratory syndrome coronavirus antibody reactors among camels in Dubai, United Arab Emirates, in 2005. Transbound. Emerg. Dis. 2014, 61, 105-108. [CrossRef] [PubMed]

66. Miguel, E.; Chevalier, V.; Ayelet, G.; Ben Bencheikh, M.N.; Boussini, H.; Chu, D.K.; El Berbri, I.; Fassi-Fihri, O.; Faye, B.; Fekadu, G.; et al. Risk factors for MERS coronavirus infection in dromedary camels in Burkina Faso, Ethiopia, and Morocco, 2015. Eurosurveillance 2017, 22, 30498. [CrossRef] [PubMed]

67. Zohaib, A.; Saqib, M.; Athar, M.A.; Chen, J.; Sial, A.U.; Khan, S.; Taj, Z.; Sadia, H.; Tahir, U.; Tayyab, M.H.; et al. Countrywide survey for MERS-coronavirus antibodies in dromedaries and humans in Pakistan. Virol. Sin. 2018, 33, 410-417. [CrossRef]

68. Saqib, M.; Sieberg, A.; Hussain, M.H.; Mansoor, M.K.; Zohaib, A.; Lattwein, E.; Muller, M.A.; Drosten, C.; Corman, V.M. Serologic evidence for MERS-CoV infection in dromedary camels, Punjab, Pakistan, 2012-2015. Emerg. Infect. Dis. 2017, 23, 550-551. [CrossRef]

69. Reusken, C.B.; Schilp, C.; Raj, V.S.; De Bruin, E.; Kohl, R.H.; Farag, E.A.; Haagmans, B.L.; Al-Romaihi, H.; Le Grange, F.; Bosch, B.J.; et al. MERS-CoV infection of alpaca in a region where MERS-CoV is endemic. Emerg. Infect. Dis. 2016, 22, 1129-1131. [CrossRef] [PubMed]

70. Rha, B.; Rudd, J.; Feikin, D.; Watson, J.; Curns, A.T.; Swerdlow, D.L.; Pallansch, M.A.; Gerber, S.I.; Centers for Disease Control and Prevention. Update on the epidemiology of Middle East respiratory syndrome coronavirus (MERS-CoV) infection, and guidance for the public, clinicians, and public health authorities-January 2015. MMWR Morb. Mortal. Wkly. Rep. 2015, 64, 61-62.

71. Zumla, A.; Hui, D.S.; Perlman, S. Middle East respiratory syndrome. Lancet 2015. [CrossRef]

72. WHO. Middle East Respiratory Syndrome Coronavirus (MERS-CoV): Summary of Current Situation, Literature Update and Risk Assessment-as of 5 February 2015; WHO: Geneva, Switzerland, 2015.

73. Fanoy, E.B.; van der Sande, M.A.; Kraaij-Dirkzwager, M.; Dirksen, K.; Jonges, M.; van der Hoek, W.; Koopmans, M.P.; van der Werf, D.; Sonder, G.; van der Weijden, C.; et al. Travel-related MERS-CoV cases: An assessment of exposures and risk factors in a group of Dutch travellers returning from the Kingdom of Saudi Arabia, May 2014. Emerg. Themes Epidemiol. 2014, 11, 16. [CrossRef]

74. WHO. MERS-CoV in the Republic of Korea at a Glance; WHO: Geneva, Switzerland, 2015.

75. Cowling, B.J.; Park, M.; Fang, V.J.; Wu, P.; Leung, G.M.; Wu, J.T. Preliminary epidemiological assessment of MERS-CoV outbreak in South Korea, May to June 2015. Eurosurveillance 2015, 20, 21163. [CrossRef]

76. Wise, J. Patient with new strain of coronavirus is treated in intensive care at London hospital. BMJ 2012, 345, e6455. [CrossRef] [PubMed]

77. WHO. Novel Coronavirus Infection in the United Kingdom; WHO: Geneva, Switzerland, 2012.

78. WHO. Middle East Respiratory Syndrome Coronavirus (MERS-CoV), Report August 2019. Available online: http://www.emro.who.int/health-topics/mers-cov/mers-outbreaks.html (accessed on 30 June 2020).

79. Sikkema, R.S.; Farag, E.; Islam, M.; Atta, M.; Reusken, C.; Al-Hajri, M.M.; Koopmans, M.P.G. Global status of Middle East respiratory syndrome coronavirus in dromedary camels: A systematic review-CORRIGENDUM. Epidemiol. Infect. 2019, 147, e198. [CrossRef] [PubMed] 
80. Reeves, T.; Samy, A.M.; Peterson, A.T. MERS-CoV geography and ecology in the Middle East: Analyses of reported camel exposures and a preliminary risk map. BMC Res. Notes 2015, 8, 801. [CrossRef] [PubMed]

81. Al-Abdallat, M.M.; Payne, D.C.; Alqasrawi, S.; Rha, B.; Tohme, R.A.; Abedi, G.R.; Al Nsour, M.; Iblan, I.; Jarour, N.; Farag, N.H.; et al. Hospital-associated outbreak of Middle East respiratory syndrome coronavirus: A serologic, epidemiologic, and clinical description. Clin. Infect. Dis. Off. Publ. Infect. Dis. Soc. Am. 2014, 59, 1225-1233. [CrossRef]

82. Memish, Z.A.; Perlman, S.; Van Kerkhove, M.D.; Zumla, A. Middle east respiratory syndrome. Lancet 2020, 395, 1063-1077. [CrossRef]

83. Corman, V.M.; Eckerle, I.; Bleicker, T.; Zaki, A.; Landt, O.; Eschbach-Bludau, M.; van Boheemen, S.; Gopal, R.; Ballhause, M.; Bestebroer, T.M.; et al. Detection of a novel human coronavirus by real-time reverse-transcription polymerase chain reaction. Eurosurveillance 2012, 17, 20285. [CrossRef]

84. CDC. Severe respiratory illness associated with a novel coronavirus—Saudi Arabia and Qatar. MMWR Morb. Mortal. Wkly. Rep. 2012, 61, 820.

85. Assiri, A.; McGeer, A.; Perl, T.M.; Price, C.S.; Al Rabeeah, A.A.; Cummings, D.A.; Alabdullatif, Z.N.; Assad, M.; Almulhim, A.; Makhdoom, H.; et al. Hospital outbreak of Middle East respiratory syndrome coronavirus. N. Engl. J. Med. 2013, 369, 407-416. [CrossRef]

86. Guery, B.; Poissy, J.; el Mansouf, L.; Sejourne, C.; Ettahar, N.; Lemaire, X.; Vuotto, F.; Goffard, A.; Behillil, S.; Enouf, V.; et al. Clinical features and viral diagnosis of two cases of infection with Middle East Respiratory Syndrome coronavirus: A report of nosocomial transmission. Lancet 2013, 381, 2265-2272. [CrossRef]

87. Oboho, I.K.; Tomczyk, S.M.; Al-Asmari, A.M.; Banjar, A.A.; Al-Mugti, H.; Aloraini, M.S.; Alkhaldi, K.Z.; Almohammadi, E.L.; Alraddadi, B.M.; Gerber, S.I.; et al. 2014 MERS-CoV outbreak in Jeddah-A link to health care facilities. N. Engl. J. Med. 2015, 372, 846-854. [CrossRef]

88. Bialek, S.R.; Allen, D.; Alvarado-Ramy, F.; Arthur, R.; Balajee, A.; Bell, D.; Best, S.; Blackmore, C.; Breakwell, L.; Cannons, A.; et al. First confirmed cases of Middle East respiratory syndrome coronavirus (MERS-CoV) infection in the United States, updated information on the epidemiology of MERS-CoV infection, and guidance for the public, clinicians, and public health authorities-May 2014. MMWR Morb. Mortal. Wkly. Rep. 2014, 63, 431-436. [PubMed]

89. Centers for Disease Control and Precention. Interim Guidelines for Collecting, Handling, and Testing Clinical Specimens from Patients under Investigation (PUIs) for Middle East Respiratory Syndrome Coronavirus (MERS-CoV); CDC: Atlanta, GA, USA, 2014; Version 2.1.

90. Park, J.; Lee, D.S.; Christakis, N.A.; Barabasi, A.L. The impact of cellular networks on disease comorbidity. Mol. Syst. Biol. 2009, 5, 262. [CrossRef] [PubMed]

91. Hui, D.S.; Azhar, E.I.; Kim, Y.J.; Memish, Z.A.; Oh, M.D.; Zumla, A. Middle East respiratory syndrome coronavirus: Risk factors and determinants of primary, household, and nosocomial transmission. Lancet Infect. Dis. 2018, 18, e217-e227. [CrossRef]

92. Badawi, A.; Ryoo, S.G. Prevalence of comorbidities in the Middle East respiratory syndrome coronavirus (MERS-CoV): A systematic review and meta-analysis. Int. J. Infect. Dis. 2016, 49, 129-133. [CrossRef]

93. Alqahtani, F.Y.; Aleanizy, F.S.; Ali El Hadi Mohamed, R.; Alanazi, M.S.; Mohamed, N.; Alrasheed, M.M.; Abanmy, N.; Alhawassi, T. Prevalence of comorbidities in cases of Middle East respiratory syndrome coronavirus: A retrospective study. Epidemiol. Infect. 2018, 147, 1-5. [CrossRef]

94. Yang, Y.-M.; Hsu, C.-Y.; Lai, C.-C.; Yen, M.-F.; Wikramaratna, P.S.; Chen, H.-H.; Wang, T.-H. Impact of comorbidity on fatality rate of patients with Middle East respiratory syndrome. Sci. Rep. 2017, 7, 11307. [CrossRef]

95. Seys, L.J.M.; Widagdo, W.; Verhamme, F.M.; Kleinjan, A.; Janssens, W.; Joos, G.F.; Bracke, K.R.; Haagmans, B.L.; Brusselle, G.G. DPP4, the Middle East respiratory syndrome coronavirus receptor, is upregulated in lungs of smokers and chronic obstructive pulmonary disease patients. Clin. Infect. Dis. Off. Publ. Infect. Dis. Soc. Am. 2018, 66, 45-53. [CrossRef]

96. Lau, S.K.; Li, K.S.; Tsang, A.K.; Lam, C.S.; Ahmed, S.; Chen, H.; Chan, K.H.; Woo, P.C.; Yuen, K.Y. Genetic characterization of Betacoronavirus lineage $C$ viruses in bats reveals marked sequence divergence in the spike protein of pipistrellus bat coronavirus HKU5 in Japanese pipistrelle: Implications for the origin of the novel Middle East respiratory syndrome coronavirus. J. Virol. 2013, 87, 8638-8650. [CrossRef] 
97. Ithete, N.L.; Stoffberg, S.; Corman, V.M.; Cottontail, V.M.; Richards, L.R.; Schoeman, M.C.; Drosten, C.; Drexler, J.F.; Preiser, W. Close relative of human Middle East respiratory syndrome coronavirus in bat, South Africa. Emerg. Infect. Dis. 2013, 19, 1697-1699. [CrossRef]

98. Hatcher, E.L.; Zhdanov, S.A.; Bao, Y.; Blinkova, O.; Nawrocki, E.P.; Ostapchuck, Y.; Schaffer, A.A.; Brister, J.R. Virus Variation Resource-Improved response to emergent viral outbreaks. Nucleic Acids Res. 2017, 45, D482-D490. [CrossRef]

99. Lau, S.K.; Wernery, R.; Wong, E.Y.; Joseph, S.; Tsang, A.K.; Patteril, N.A.; Elizabeth, S.K.; Chan, K.H.; Muhammed, R.; Kinne, J.; et al. Polyphyletic origin of MERS coronaviruses and isolation of a novel clade A strain from dromedary camels in the United Arab Emirates. Emerg. Microbes Infect. 2016, 5, e128. [CrossRef] [PubMed]

100. Frey, K.G.; Redden, C.L.; Bishop-Lilly, K.A.; Johnson, R.; Hensley, L.E.; Raviprakash, K.; Luke, T.; Kochel, T.; Mokashi, V.P.; Defang, G.N. Full-genome sequence of human betacoronavirus 2c jordan-n3/2012 after serial passage in Mammalian cells. Genome Announc. 2014, 2. [CrossRef] [PubMed]

101. Kandeil, A.; Shehata, M.M.; El Shesheny, R.; Gomaa, M.R.; Ali, M.A.; Kayali, G. Complete genome sequence of Middle East respiratory syndrome coronavirus isolated from a dromedary camel in Egypt. Genome Announc. 2016, 4. [CrossRef] [PubMed]

102. Kleine-Weber, H.; Elzayat, M.T.; Wang, L.; Graham, B.S.; Muller, M.A.; Drosten, C.; Pohlmann, S.; Hoffmann, M. Mutations in the spike protein of Middle East respiratory syndrome coronavirus transmitted in Korea increase resistance to antibody-mediated neutralization. J. Virol. 2019, 93. [CrossRef]

103. Kim, Y.; Cheon, S.; Min, C.K.; Sohn, K.M.; Kang, Y.J.; Cha, Y.J.; Kang, J.I.; Han, S.K.; Ha, N.Y.; Kim, G.; et al. Spread of mutant Middle East respiratory syndrome coronavirus with reduced affinity to human CD26 during the South Korean outbreak. mBio 2016, 7, e00019. [CrossRef]

104. Zhang, Z.; Shen, L.; Gu, X. Evolutionary dynamics of MERS-CoV: Potential recombination, positive selection and transmission. Sci. Rep. 2016, 6, 25049. [CrossRef]

105. Drosten, C.; Muth, D.; Corman, V.M.; Hussain, R.; Al Masri, M.; HajOmar, W.; Landt, O.; Assiri, A.; Eckerle, I.; Al Shangiti, A.; et al. An observational, laboratory-based study of outbreaks of middle East respiratory syndrome coronavirus in Jeddah and Riyadh, kingdom of Saudi Arabia, 2014. Clin. Infect. Dis. Off. Publ. Infect. Dis. Soc. Am. 2015, 60, 369-377. [CrossRef]

106. Fagbo, S.F.; Skakni, L.; Chu, D.K.; Garbati, M.A.; Joseph, M.; Peiris, M.; Hakawi, A.M. Molecular epidemiology of hospital outbreak of Middle East respiratory syndrome, Riyadh, Saudi Arabia, 2014. Emerg. Infect. Dis. 2015, 21, 1981-1988. [CrossRef]

107. Forni, D.; Filippi, G.; Cagliani, R.; De Gioia, L.; Pozzoli, U.; Al-Daghri, N.; Clerici, M.; Sironi, M. The heptad repeat region is a major selection target in MERS-CoV and related coronaviruses. Sci. Rep. 2015, 5, 14480. [CrossRef]

108. Cotten, M.; Watson, S.J.; Zumla, A.I.; Makhdoom, H.Q.; Palser, A.L.; Ong, S.H.; Al Rabeeah, A.A.; Alhakeem, R.F.; Assiri, A.; Al-Tawfiq, J.A.; et al. Spread, circulation, and evolution of the Middle East respiratory syndrome coronavirus. mBio 2014, 5. [CrossRef]

109. Hunter, J.C.; Nguyen, D.; Aden, B.; Al Bandar, Z.; Al Dhaheri, W.; Abu Elkheir, K.; Khudair, A.; Al Mulla, M.; El Saleh, F.; Imambaccus, H.; et al. Transmission of Middle East respiratory syndrome coronavirus infections in healthcare settings, Abu Dhabi. Emerg. Infect. Dis. 2016, 22, 647-656. [CrossRef] [PubMed]

110. Yang, Y.; Liu, C.; Du, L.; Jiang, S.; Shi, Z.; Baric, R.S.; Li, F. Two mutations were critical for bat-to-human transmission of Middle East respiratory syndrome coronavirus. J. Virol. 2015, 89, 9119. [CrossRef] [PubMed]

111. Li, K.; Wohlford-Lenane, C.L.; Channappanavar, R.; Park, J.E.; Earnest, J.T.; Bair, T.B.; Bates, A.M.; Brogden, K.A.; Flaherty, H.A.; Gallagher, T.; et al. Mouse-adapted MERS coronavirus causes lethal lung disease in human DPP4 knockin mice. Proc. Natl. Acad. Sci. USA 2017, 114, E3119-E3128. [CrossRef] [PubMed]

112. de Wit, E.; Feldmann, F.; Cronin, J.; Jordan, R.; Okumura, A.; Thomas, T.; Scott, D.; Cihlar, T.; Feldmann, H. Prophylactic and therapeutic remdesivir (GS-5734) treatment in the rhesus macaque model of MERS-CoV infection. Proc. Natl. Acad. Sci. USA 2020, 117, 6771-6776. [CrossRef]

113. Cong, Y.; Hart, B.J.; Gross, R.; Zhou, H.; Frieman, M.; Bollinger, L.; Wada, J.; Hensley, L.E.; Jahrling, P.B.; Dyall, J.; et al. MERS-CoV pathogenesis and antiviral efficacy of licensed drugs in human monocyte-derived antigen-presenting cells. PLoS ONE 2018, 13, e0194868. [CrossRef] 
114. Sheahan, T.P.; Sims, A.C.; Leist, S.R.; Schäfer, A.; Won, J.; Brown, A.J.; Montgomery, S.A.; Hogg, A.; Babusis, D.; Clarke, M.O.; et al. Comparative therapeutic efficacy of remdesivir and combination lopinavir, ritonavir, and interferon beta against MERS-CoV. Nat. Commun. 2020, 11, 222. [CrossRef]

115. Dyall, J.; Coleman, C.M.; Hart, B.J.; Venkataraman, T.; Holbrook, M.R.; Kindrachuk, J.; Johnson, R.F.; Olinger, G.G., Jr.; Jahrling, P.B.; Laidlaw, M.; et al. Repurposing of clinically developed drugs for treatment of Middle East respiratory syndrome coronavirus infection. Antimicrob. Agents Chemother. 2014, 58, 4885-4893. [CrossRef]

116. Burkard, C.; Verheije, M.H.; Haagmans, B.L.; van Kuppeveld, F.J.; Rottier, P.J.; Bosch, B.J.; de Haan, C.A. ATP1A1-mediated Src signaling inhibits coronavirus entry into host cells. J. Virol. 2015, 89, 4434-4448. [CrossRef]

117. Shirato, K.; Kawase, M.; Matsuyama, S. Middle East respiratory syndrome coronavirus infection mediated by the transmembrane serine protease TMPRSS2. J. Virol. 2013, 87, 12552-12561. [CrossRef]

118. Muller, C.; Schulte, F.W.; Lange-Grunweller, K.; Obermann, W.; Madhugiri, R.; Pleschka, S.; Ziebuhr, J.; Hartmann, R.K.; Grunweller, A. Broad-spectrum antiviral activity of the eIF4A inhibitor silvestrol against corona- and picornaviruses. Antivir. Res. 2018, 150, 123-129. [CrossRef]

119. Agostini, M.L.; Andres, E.L.; Sims, A.C.; Graham, R.L.; Sheahan, T.P.; Lu, X.; Smith, E.C.; Case, J.B.; Feng, J.Y.; Jordan, R.; et al. Coronavirus susceptibility to the antiviral remdesivir (GS-5734) is mediated by the viral polymerase and the proofreading exoribonuclease. mBio 2018, 9. [CrossRef] [PubMed]

120. Shin, J.S.; Jung, E.; Kim, M.; Baric, R.S.; Go, Y.Y. Saracatinib inhibits Middle East respiratory syndrome-coronavirus replication in vitro. Viruses 2018, 10, 283. [CrossRef] [PubMed]

121. de Wilde, A.H.; Raj, V.S.; Oudshoorn, D.; Bestebroer, T.M.; van Nieuwkoop, S.; Limpens, R.; Posthuma, C.C.; van der Meer, Y.; Bárcena, M.; Haagmans, B.L.; et al. MERS-coronavirus replication induces severe in vitro cytopathology and is strongly inhibited by cyclosporin A or interferon- $\alpha$ treatment. J. Gen. Virol. 2013, 94, 1749-1760. [CrossRef] [PubMed]

122. Kindrachuk, J.; Ork, B.; Hart, B.J.; Mazur, S.; Holbrook, M.R.; Frieman, M.B.; Traynor, D.; Johnson, R.F.; Dyall, J.; Kuhn, J.H.; et al. Antiviral potential of ERK/MAPK and PI3K/AKT/mTOR signaling modulation for Middle East respiratory syndrome coronavirus infection as identified by temporal kinome analysis. Antimicrob. Agents Chemother. 2015, 59, 1088-1099. [CrossRef]

123. de Wilde, A.H.; Jochmans, D.; Posthuma, C.C.; Zevenhoven-Dobbe, J.C.; van Nieuwkoop, S.; Bestebroer, T.M.; van den Hoogen, B.G.; Neyts, J.; Snijder, E.J. Screening of an FDA-approved compound library identifies four small-molecule inhibitors of Middle East respiratory syndrome coronavirus replication in cell culture. Antimicrob. Agents Chemother. 2014, 58, 4875-4884. [CrossRef] [PubMed]

124. Zhou, J.; Chu, H.; Li, C.; Wong, B.H.; Cheng, Z.S.; Poon, V.K.; Sun, T.; Lau, C.C.; Wong, K.K.; Chan, J.Y.; et al. Active replication of Middle East respiratory syndrome coronavirus and aberrant induction of inflammatory cytokines and chemokines in human macrophages: Implications for pathogenesis. J. Infect. Dis. 2014, 209, 1331-1342. [CrossRef]

125. Lin, S.C.; Ho, C.T.; Chuo, W.H.; Li, S.; Wang, T.T.; Lin, C.C. Effective inhibition of MERS-CoV infection by resveratrol. BMC Infect. Dis. 2017, 17, 144. [CrossRef]

126. DeZure, A.D.; Berkowitz, N.M.; Graham, B.S.; Ledgerwood, J.E. Whole-inactivated and virus-like particle vaccine strategies for chikungunya virus. J. Infect. Dis. 2016, 214, S497-S499. [CrossRef]

127. Shehata, M.M.; Mostafa, A.; Teubner, L.; Mahmoud, S.H.; Kandeil, A.; Elshesheny, R.; Frantz, R.; La Pietra, L.; Pleschka, S.; Osman, A.; et al. Bacterial Outer Membrane Vesicles (OMVs)-based dual vaccine for influenza A H1N1 virus and MERS-CoV. Vaccines 2019, 7, 46. [CrossRef]

128. Deng, Y.; Lan, J.; Bao, L.; Huang, B.; Ye, F.; Chen, Y.; Yao, Y.; Wang, W.; Qin, C.; Tan, W. Enhanced protection in mice induced by immunization with inactivated whole viruses compare to spike protein of middle east respiratory syndrome coronavirus. Emerg. Microbes Infect. 2018, 7, 60. [CrossRef]

129. Wirblich, C.; Coleman, C.M.; Kurup, D.; Abraham, T.S.; Bernbaum, J.G.; Jahrling, P.B.; Hensley, L.E.; Johnson, R.F.; Frieman, M.B.; Schnell, M.J. One-Health: A safe, efficient, dual-use vaccine for humans and animals against Middle East respiratory syndrome coronavirus and rabies virus. J. Virol. 2017, 91. [CrossRef] [PubMed] 
130. Agrawal, A.S.; Tao, X.; Algaissi, A.; Garron, T.; Narayanan, K.; Peng, B.H.; Couch, R.B.; Tseng, C.T. Immunization with inactivated Middle East Respiratory Syndrome coronavirus vaccine leads to lung immunopathology on challenge with live virus. Hum. Vaccines Immunother. 2016, 12, 2351-2356. [CrossRef] [PubMed]

131. Tseng, C.T.; Sbrana, E.; Iwata-Yoshikawa, N.; Newman, P.C.; Garron, T.; Atmar, R.L.; Peters, C.J.; Couch, R.B. Immunization with SARS coronavirus vaccines leads to pulmonary immunopathology on challenge with the SARS virus. PLoS ONE 2012, 7, e35421. [CrossRef]

132. Shehata, M.M.; Kandeil, A.; Mostafa, A.; Mahmoud, S.H.; Gomaa, M.R.; El-Shesheny, R.; Webby, R.; Kayali, G.; Ali, M.A. A Recombinant Influenza A/H1N1 Carrying A Short Immunogenic Peptide of MERS-CoV as Bivalent Vaccine in BALB/c Mice. Pathogens 2019, 8, 281. [CrossRef]

133. Almazan, F.; DeDiego, M.L.; Sola, I.; Zuniga, S.; Nieto-Torres, J.L.; Marquez-Jurado, S.; Andres, G.; Enjuanes, L. Engineering a replication-competent, propagation-defective Middle East respiratory syndrome coronavirus as a vaccine candidate. $m$ Bio 2013, 4, e00650-13. [CrossRef]

134. Malczyk, A.H.; Kupke, A.; Prufer, S.; Scheuplein, V.A.; Hutzler, S.; Kreuz, D.; Beissert, T.; Bauer, S.; Hubich-Rau, S.; Tondera, C.; et al. A highly immunogenic and protective Middle East respiratory syndrome coronavirus vaccine based on a recombinant measles virus vaccine platform. J. Virol. 2015, 89, 11654-11667. [CrossRef]

135. Menachery, V.D.; Gralinski, L.E.; Mitchell, H.D.; Dinnon, K.H., 3rd; Leist, S.R.; Yount, B.L., Jr.; Graham, R.L.; McAnarney, E.T.; Stratton, K.G.; Cockrell, A.S.; et al. Middle East respiratory syndrome coronavirus nonstructural protein 16 is necessary for interferon resistance and viral pathogenesis. mSphere 2017, 2. [CrossRef]

136. Bodmer, B.S.; Fiedler, A.H.; Hanauer, J.R.H.; Prufer, S.; Muhlebach, M.D. Live-attenuated bivalent measles virus-derived vaccines targeting Middle East respiratory syndrome coronavirus induce robust and multifunctional $\mathrm{T}$ cell responses against both viruses in an appropriate mouse model. Virology 2018, 521, 99-107. [CrossRef]

137. Liu, R.; Wang, J.; Shao, Y.; Wang, X.; Zhang, H.; Shuai, L.; Ge, J.; Wen, Z.; Bu, Z. A recombinant VSV-vectored MERS-CoV vaccine induces neutralizing antibody and $\mathrm{T}$ cell responses in rhesus monkeys after single dose immunization. Antivir. Res. 2018, 150, 30-38. [CrossRef]

138. Kato, H.; Takayama-Ito, M.; Iizuka-Shiota, I.; Fukushi, S.; Posadas-Herrera, G.; Horiya, M.; Satoh, M.; Yoshikawa, T.; Yamada, S.; Harada, S.; et al. Development of a recombinant replication-deficient rabies virus-based bivalent-vaccine against MERS-CoV and rabies virus and its humoral immunogenicity in mice. PLoS ONE 2019, 14, e0223684. [CrossRef]

139. Du, L.; Tai, W.; Zhou, Y.; Jiang, S. Vaccines for the prevention against the threat of MERS-CoV. Expert Rev. Vaccines 2016, 15, 1123-1134. [CrossRef] [PubMed]

140. Du, L.; Kou, Z.; Ma, C.; Tao, X.; Wang, L.; Zhao, G.; Chen, Y.; Yu, F.; Tseng, C.T.; Zhou, Y.; et al. A truncated receptor-binding domain of MERS-CoV spike protein potently inhibits MERS-CoV infection and induces strong neutralizing antibody responses: Implication for developing therapeutics and vaccines. PLoS ONE 2013, 8, e81587. [CrossRef]

141. Ma, C.; Wang, L.; Tao, X.; Zhang, N.; Yang, Y.; Tseng, C.T.; Li, F.; Zhou, Y.; Jiang, S.; Du, L. Searching for an ideal vaccine candidate among different MERS coronavirus receptor-binding fragments-the importance of immunofocusing in subunit vaccine design. Vaccine 2014, 32, 6170-6176. [CrossRef] [PubMed]

142. Mou, H.; Raj, V.S.; van Kuppeveld, F.J.; Rottier, P.J.; Haagmans, B.L.; Bosch, B.J. The receptor binding domain of the new Middle East respiratory syndrome coronavirus maps to a 231-residue region in the spike protein that efficiently elicits neutralizing antibodies. J. Virol. 2013, 87, 9379-9383. [CrossRef] [PubMed]

143. Zhao, G.; Du, L.; Ma, C.; Li, Y.; Li, L.; Poon, V.K.; Wang, L.; Yu, F.; Zheng, B.J.; Jiang, S.; et al. A safe and convenient pseudovirus-based inhibition assay to detect neutralizing antibodies and screen for viral entry inhibitors against the novel human coronavirus MERS-CoV. Virol. J. 2013, 10, 266. [CrossRef]

144. Lan, J.; Deng, Y.; Chen, H.; Lu, G.; Wang, W.; Guo, X.; Lu, Z.; Gao, G.F.; Tan, W. Tailoring subunit vaccine immunity with adjuvant combinations and delivery routes using the Middle East respiratory coronavirus (MERS-CoV) receptor-binding domain as an antigen. PLoS ONE 2014, 9, e112602. [CrossRef]

145. Zhang, N.; Channappanavar, R.; Ma, C.; Wang, L.; Tang, J.; Garron, T.; Tao, X.; Tasneem, S.; Lu, L.; Tseng, C.T.; et al. Identification of an ideal adjuvant for receptor-binding domain-based subunit vaccines against Middle East respiratory syndrome coronavirus. Cell. Mol. Immunol. 2016, 13, 180-190. [CrossRef] 
146. Lan, J.; Deng, Y.; Song, J.; Huang, B.; Wang, W.; Tan, W. Significant spike-specific IgG and neutralizing antibodies in mice induced by a novel chimeric virus-like particle vaccine candidate for Middle East respiratory syndrome coronavirus. Virol. Sin. 2018, 33, 453-455. [CrossRef]

147. Tai, W.; Zhao, G.; Sun, S.; Guo, Y.; Wang, Y.; Tao, X.; Tseng, C.K.; Li, F.; Jiang, S.; Du, L.; et al. A recombinant receptor-binding domain of MERS-CoV in trimeric form protects human dipeptidyl peptidase 4 (hDPP4) transgenic mice from MERS-CoV infection. Virology 2016, 499, 375-382. [CrossRef]

148. Pallesen, J.; Wang, N.; Corbett, K.S.; Wrapp, D.; Kirchdoerfer, R.N.; Turner, H.L.; Cottrell, C.A.; Becker, M.M.; Wang, L.; Shi, W.; et al. Immunogenicity and structures of a rationally designed prefusion MERS-CoV spike antigen. Proc. Natl. Acad. Sci. USA 2017, 114, E7348-E7357. [CrossRef]

149. Coleman, C.M.; Liu, Y.V.; Mu, H.; Taylor, J.K.; Massare, M.; Flyer, D.C.; Glenn, G.M.; Smith, G.E.; Frieman, M.B. Purified coronavirus spike protein nanoparticles induce coronavirus neutralizing antibodies in mice. Vaccine 2014, 32, 3169-3174. [CrossRef] [PubMed]

150. Jiaming, L.; Yanfeng, Y.; Yao, D.; Yawei, H.; Linlin, B.; Baoying, H.; Jinghua, Y.; Gao, G.F.; Chuan, Q.; Wenjie, T. The recombinant $\mathrm{N}$-terminal domain of spike proteins is a potential vaccine against Middle East respiratory syndrome coronavirus (MERS-CoV) infection. Vaccine 2017, 35, 10-18. [CrossRef] [PubMed]

151. Wang, L.; Shi, W.; Joyce, M.G.; Modjarrad, K.; Zhang, Y.; Leung, K.; Lees, C.R.; Zhou, T.; Yassine, H.M.; Kanekiyo, M.; et al. Evaluation of candidate vaccine approaches for MERS-CoV. Nat. Commun. 2015, 6, 7712. [CrossRef] [PubMed]

152. Adney, D.R.; Wang, L.; van Doremalen, N.; Shi, W.; Zhang, Y.; Kong, W.P.; Miller, M.R.; Bushmaker, T.; Scott, D.; de Wit, E.; et al. Efficacy of an adjuvanted Middle East respiratory syndrome coronavirus spike protein vaccine in dromedary camels and alpacas. Viruses 2019, 11, 212. [CrossRef] [PubMed]

153. Wang, C.; Zheng, X.; Gai, W.; Wong, G.; Wang, H.; Jin, H.; Feng, N.; Zhao, Y.; Zhang, W.; Li, N.; et al. Novel chimeric virus-like particles vaccine displaying MERS-CoV receptor-binding domain induce specific humoral and cellular immune response in mice. Antivir. Res. 2017, 140, 55-61. [CrossRef]

154. Wang, C.; Zheng, X.; Gai, W.; Zhao, Y.; Wang, H.; Wang, H.; Feng, N.; Chi, H.; Qiu, B.; Li, N.; et al. MERS-CoV virus-like particles produced in insect cells induce specific humoural and cellular imminity in rhesus macaques. Oncotarget 2017, 8, 12686-12694. [CrossRef]

155. Guo, X.; Deng, Y.; Chen, H.; Lan, J.; Wang, W.; Zou, X.; Hung, T.; Lu, Z.; Tan, W. Systemic and mucosal immunity in mice elicited by a single immunization with human adenovirus type 5 or 41 vector-based vaccines carrying the spike protein of Middle East respiratory syndrome coronavirus. Immunology 2015, 145, 476-484. [CrossRef]

156. Kim, E.; Okada, K.; Kenniston, T.; Raj, V.S.; AlHajri, M.M.; Farag, E.A.; AlHajri, F.; Osterhaus, A.D.; Haagmans, B.L.; Gambotto, A. Immunogenicity of an adenoviral-based Middle East Respiratory Syndrome coronavirus vaccine in BALB/c mice. Vaccine 2014, 32, 5975-5982. [CrossRef]

157. Hashem, A.M.; Algaissi, A.; Agrawal, A.; Al-Amri, S.S.; Alhabbab, R.Y.; Sohrab, S.S.; Almasoud, A.; Alharbi, N.K.; Peng, B.H.; Russell, M.; et al. A highly immunogenic, protective and safe adenovirus-based vaccine expressing MERS-CoV S1-CD40L fusion protein in transgenic human DPP4 mouse model. J. Infect. Dis. 2019. [CrossRef]

158. Alharbi, N.K.; Padron-Regalado, E.; Thompson, C.P.; Kupke, A.; Wells, D.; Sloan, M.A.; Grehan, K.; Temperton, N.; Lambe, T.; Warimwe, G.; et al. ChAdOx1 and MVA based vaccine candidates against MERS-CoV elicit neutralising antibodies and cellular immune responses in mice. Vaccine 2017, 35, 3780-3788. [CrossRef]

159. Munster, V.J.; Wells, D.; Lambe, T.; Wright, D.; Fischer, R.J.; Bushmaker, T.; Saturday, G.; van Doremalen, N.; Gilbert, S.C.; de Wit, E.; et al. Protective efficacy of a novel simian adenovirus vaccine against lethal MERS-CoV challenge in a transgenic human DPP4 mouse model. NPJ Vaccines 2017, 2, 28. [CrossRef]

160. Song, F.; Fux, R.; Provacia, L.B.; Volz, A.; Eickmann, M.; Becker, S.; Osterhaus, A.D.; Haagmans, B.L.; Sutter, G. Middle East respiratory syndrome coronavirus spike protein delivered by modified vaccinia virus Ankara efficiently induces virus-neutralizing antibodies. J. Virol. 2013, 87, 11950-11954. [CrossRef] [PubMed]

161. Volz, A.; Kupke, A.; Song, F.; Jany, S.; Fux, R.; Shams-Eldin, H.; Schmidt, J.; Becker, C.; Eickmann, M.; Becker, S.; et al. Protective efficacy of recombinant Modified Vaccinia virus Ankara (MVA) delivering Middle East Respiratory Syndrome coronavirus spike glycoprotein. J. Virol. 2015. [CrossRef] [PubMed] 
162. Zhao, J.; Li, K.; Wohlford-Lenane, C.; Agnihothram, S.S.; Fett, C.; Zhao, J.; Gale, M.J., Jr.; Baric, R.S.; Enjuanes, L.; Gallagher, T.; et al. Rapid generation of a mouse model for Middle East respiratory syndrome. Proc. Natl. Acad. Sci. USA 2014, 111, 4970-4975. [CrossRef] [PubMed]

163. Liu, R.Q.; Ge, J.-Y.; Wang, J.-L.; Shao, Y.; Zhang, H.-L.; Wang, J.-L.; Wen, Z.-Y.; Bu, Z.-G. Newcastle disease virus-based mers-cov candidate vaccine elicits high-level and lasting neutralizing antibodies in bactrian camels. J. Integr. Agric. 2017, 16. [CrossRef]

164. Muthumani, K.; Falzarano, D.; Reuschel, E.L.; Tingey, C.; Flingai, S.; Villarreal, D.O.; Wise, M.; Patel, A.; Izmirly, A.; Aljuaid, A.; et al. A synthetic consensus anti-spike protein DNA vaccine induces protective immunity against Middle East respiratory syndrome coronavirus in nonhuman primates. Sci. Transl. Med. 2015, 7, 301ra132. [CrossRef]

165. Chi, H.; Zheng, X.; Wang, X.; Wang, C.; Wang, H.; Gai, W.; Perlman, S.; Yang, S.; Zhao, J.; Xia, X. DNA vaccine encoding Middle East respiratory syndrome coronavirus S1 protein induces protective immune responses in mice. Vaccine 2017, 35, 2069-2075. [CrossRef]

166. Al-Amri, S.S.; Abbas, A.T.; Siddiq, L.A.; Alghamdi, A.; Sanki, M.A.; Al-Muhanna, M.K.; Alhabbab, R.Y.; Azhar, E.I.; Li, X.; Hashem, A.M. Immunogenicity of candidate MERS-CoV DNA vaccines based on the spike protein. Sci. Rep. 2017, 7, 44875. [CrossRef]

(C) 2020 by the authors. Licensee MDPI, Basel, Switzerland. This article is an open access article distributed under the terms and conditions of the Creative Commons Attribution (CC BY) license (http://creativecommons.org/licenses/by/4.0/). 